Portland State University

PDXScholar

6-11-1993

\title{
A Study of Gender and Personality Factors in Work- Family Conflict Models
}

Steven Donald Ward

Portland State University

Follow this and additional works at: https://pdxscholar.library.pdx.edu/open_access_etds

Part of the Psychology Commons

Let us know how access to this document benefits you.

\section{Recommended Citation}

Ward, Steven Donald, "A Study of Gender and Personality Factors in Work-Family Conflict Models" (1993). Dissertations and Theses. Paper 4757.

https://doi.org/10.15760/etd.6641

This Thesis is brought to you for free and open access. It has been accepted for inclusion in Dissertations and Theses by an authorized administrator of PDXScholar. Please contact us if we can make this document more accessible: pdxscholar@pdx.edu. 
AN ABSTRACT OF THE THESIS OF Steven Donald Ward for the Master of Science in Psychology presented June 11, 1993.

Title: A Study of Gender and Personality Factors in workFamily Conflict Models

APPROVED BY THE MEMBERS OF THE THESIS COMMITTEE:
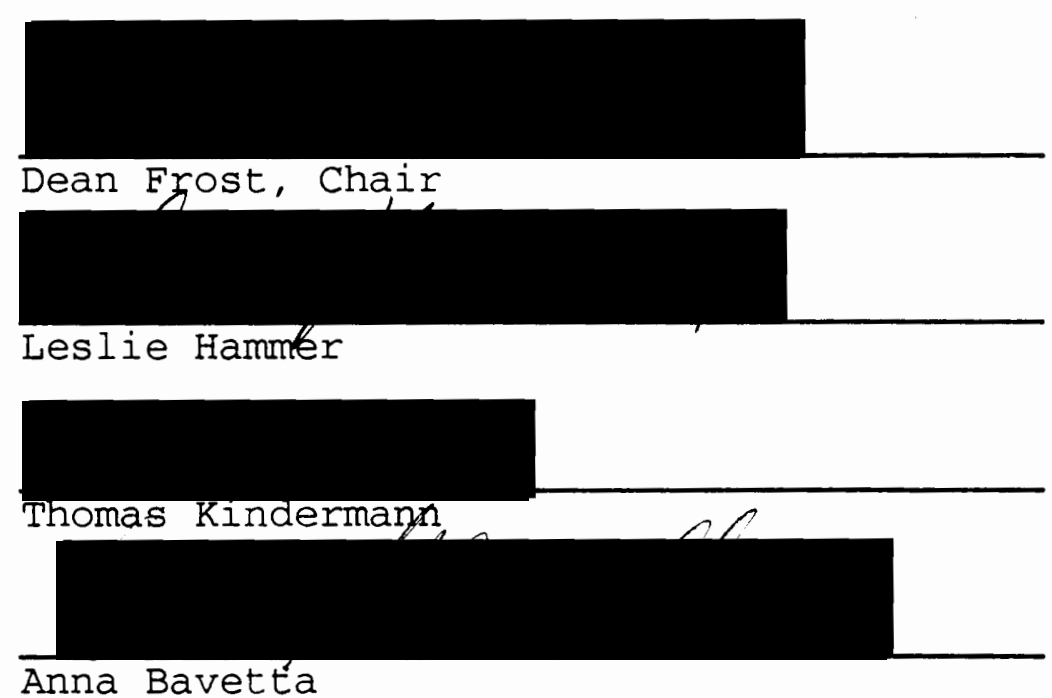

There were three underlying purposes to this study: 1) To test the main effect of gender on work $->$ family and family $\rightarrow$ work conflict; 2) To re-examine the predictors of inter-role conflict used by Frone, Russell, and Cooper (1992) (i.e., job involvement, job stress, family involvement, and family stress); and 3) To investigate the importance of using personality characteristics as predictors of how individuals deal with inter-role conflict. A questionnaire was assembled, consisting of: a work $\rightarrow$ family conflict spillover scale, a 
family $\rightarrow$ work conflict spillover scale, a job involvement scale, a family involvement scale, a job stressors scale, a family stressors scale, and two sub-scales from the California Psychological Inventory (i.e., the Managerial Potential scale and the Work Orientation scale). Questionnaires were completed by 134 employees of a civil service agency. Results indicated that gender was not a significant predictor of either work -> family or family -> work conflict. Job stress was found to be a significant predictor of both work $\rightarrow$ family, and family $\rightarrow$ work conflict. Where as family stress was found to be a significant predictor of family -> work conflict only. Job involvement was found to be a significant predictor of work $\rightarrow$ family conflict for managers only. When all predictors were assessed simultaneously, Work Orientation was the only variable found to be a significant predictor of work $\rightarrow$ family conflict. The results from this study clarify and add to Frone, Russell, and Cooper's (1992) study of the work-family interface. 
A STUDY OF GENDER AND PERSONALITY FACTORS

IN WORK-FAMILY CONFLICT MODELS

\author{
by \\ STEVEN DONALD WARD
}

A thesis submitted in partial fulfillment of the requirements for the degree of

\author{
MASTER OF SCIENCE \\ in \\ PSYCHOLOGY
}

Portland State University

1993 
TO THE OFFICE OF GRADUATE STUDIES:

The members of the committee approve the thesis of Steven Donald Ward presented June 11, 1993.

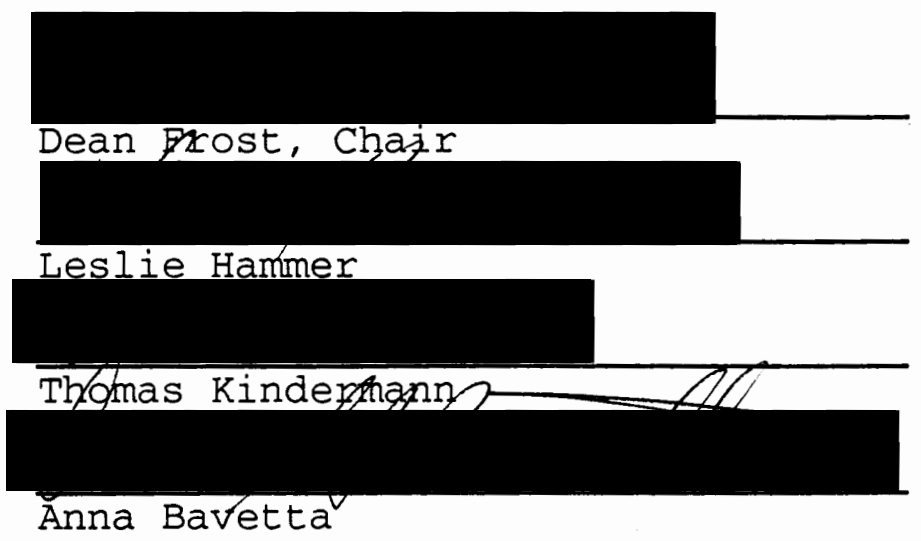

APPROVED :

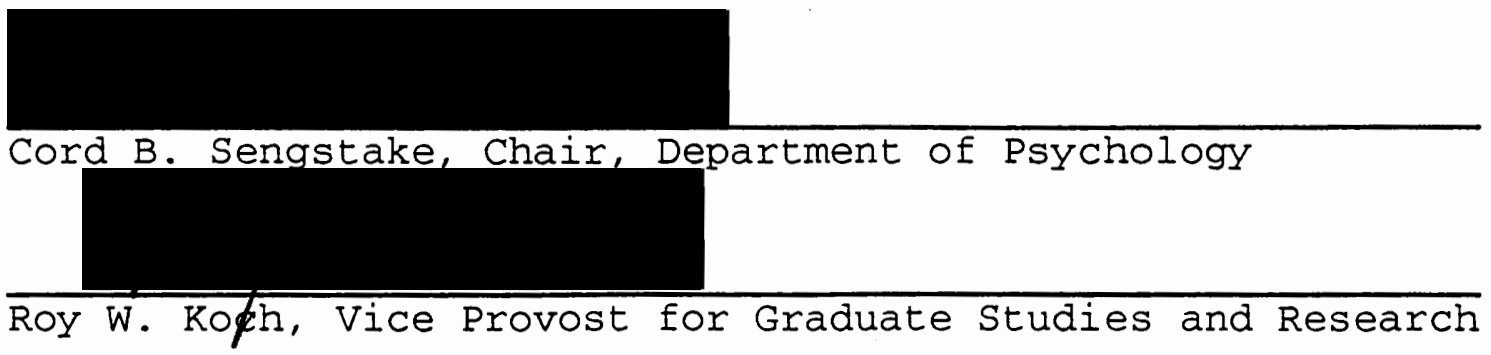


TABLE OF CONTENTS

PAGE

LIST OF TABLES . . . . . . . . . . . . . . . . . . . v

LIST OF FIGURES . . . . . . . . . . . . . . . . . . . . . vi

INTRODUCTION . . . . . . . . . . . . . . . . . . . . . 1

Problem Statement . . . . . . . . . . . . . . . 1

Theoretical Background . . . . . . . . . . . . . 2

Recent Research . . . . . . . . . . . . . . 6

Goals of This Study . . . . . . . . . . . . . 8

Research Hypotheses . . . . . . . . . . . . . 12

METHODS . . . . . . . . . . . . . . . . . . . 16

Subjects . . . . . . . . . . . . . . . . 16

Instruments . . . . . . . . . . . . . . . . . . 16

Procedure . . . . . . . . . . . . . . . . . 24

Analyses . . . . . . . . . . . . . . . . . 24

RESULTS . . . . . . . . . . . . . . . . . . . . . 28

Descriptive Statistics . . . . . . . . . . 28

Tests of Hypotheses . . . . . . . . . . . . 30

DISCUSSION . . . . . . . . . . . . . . . . . . . . . . 40

Discussion of Hypotheses . . . . . . . . . . . . 40

Theoretical Implications . . . . . . . . . . . . 49 
Practical Implications . . . . . . . . . . . . 52

Future Research Needs . . . . . . . . . . . . 53

REFERENCES . . . . . . . . . . . . . . . . . . . . . . 56

APPENDICES

A FRONE, RUSSEL, AND COOPER (1992b) CONCEPTUAL MODEL

OF THE WORK-FAMILY INTERFACE . . . . . . . . . . 59

B MODEL ILLUSTRATING TEST OF EACH PREDICTOR FOR

WORK $\rightarrow$ FAMILY CONFLICT . . . . . . . . . . . . . .61

C QUESTIONNAIRE . . . . . . . . . . . . . . . . . . 63 


\section{LIST OF TABLES}

TABLE

PAGE

I A Comparison of Means and Standard Deviations for Scales Used in This Study and Frone et al.'s 1992b study . . . . . . . . . . . . . . . . 29

II A Comparison of Reliability Estimates for Scales Used in This Study and Frone et al.'s 1992b Study . . . . . . . . . . . . . . . . 30

II Intercorrelation Matrix for Scales . . . . . . 30

IV Regression Equation for Hypothesis 1: Predicting Reports of Work -> Family Conflict . . . . . . . 31

$\mathrm{V}$ Regression Equation for Follow-up Analysis of Job Involvement . . . . . . . . . . . . . . 33

VI Regression Equation for Hypothesis 2: Predicting Reports of Family $\rightarrow$ Work Conflict . . . . . . . 35

VII Regression Equations for Hypothesis 3: Tests of Gender as a Predictor of Inter-role conflict . . 36

VIII Zero-Order Correlations for Hypothesis 4: Testing the Relationship Between Motivational Variables and Inter-Role Conflict . . . . . . . . . . 37

IX Regression Equation for Hypothesis 5: A Test of Motivational Variables as Predictors of Work $>$ Family Conflict . . . . . . . . . . 39 


\section{LIST OF FIGURES}

FIGURE

PAGE

1 The Relationship Between Management and Job

Involvement . . . . . . . . . . . . . . . . . 
INTRODUCTION

PROBLEM STATEMENT

In what has been referred to as a "classic paper on workfamily dynamics" (Frone, Russell, \& Cooper, 1992a, p.3), Pleck (1977) suggested that the permeability of the boundaries between work roles and family roles were asymmetrical (e.g., conflict in one's work role may effect one's family role, but not vice versa), and that a gender difference exists for the directionality of the boundary penetration. In other words, a female's family role will interfere with her role at work, but this is less true for males. A male's work role will interfere with his family role, but this is less true for females.

Further investigation of these gender differences has only recently appeared in the work-family literature. In three recent articles (Frone, Russell, \& Cooper, 1992a, 1992b; Hall \& Richter, 1988) no significant gender differences were discovered. However, partial support for Pleck's 1977 findings can still be found (Duxbury \& Higgins, 1991).

The purpose of this study was to further investigate the effects of gender on inter-role conflict (i.e., conflict between an individual's work roles and family roles), while examining alternative explanations as well (i.e., the effects 
of personality variables). Three sets of variables were assessed for their influence on inter-role conflict: 1) an individual's psychological/behavioral involvement and stress in the work domain and family domain; 2) the gender of the individual; and 3) the individual's motivation to manage and work values.

\section{THEORETICAL BACKGROUND}

The relationship between work and family has been under investigation for some time. Studies of this relationship have been conducted by child and marriage specialists, community psychologists, demographers, economists, family sociologists, family therapists, occupational sociologists, industrial analysts, industrial and organizational psychologists, and vocational psychologists (Zedeck \& Mosier, 1990). Work-family conflict is a form of inter-role conflict (i.e., such conflict reflects pressures to perform one role in an individual's life, which in turn contends with another role that the individual feels pressure to perform). Three types of inter-role conflict have been identified within work-family conflict. These three conflicts have been defined as follows (Kahn, Wolfe, Quinn, Snoek, \& Rosenthal, 1964):

1) Time-Based Conflict is simply demand on an individual's time. For example, the time required to perform one role may not leave enough time to 
perform another role (Greenhaus \& Beutell, 1985; Kahn et al., 1964).

2) Strain-Based Conflict occurs when performance of one role has caused exhaustion, anxiety, depression, tension, irritability, and/or apathy. These effects could hamper performances of other roles in an individual's life (Greenhaus \& Beutell, 1985; Kahn et al., 1964).

3) Behavior-Based Conflict occurs when behavior in one role is incompatible with expected behavior in another role. For example, behaviors required to perform a managerial role at work may be inharmonious with an individual's role at home (Greenhaus \& Beutell, 1985; Kahn et al., 1964).

A review of work-family conflict literature reveals three dominant theories which attempt to explain how these two domains interact.

1) The spillover theory suggests that there is a relationship between one's work domain and family domain so that each have an effect on the other. Individuals carry their emotions, attitudes, skills, and behaviors from one domain to the other (Lambert, 1990). The role that an individual adheres to in one domain will have an effect on the manner in which roles will be played out in the other domain. This cross-domain influence can be either positive or negative 
(Evans \& Bartolome, 1984; Lambert, 1990; Piotrowski's 1978 study cited in zedeck \& Mosier, 1990). For example, if an individual is going through a divorce in his or her family domain, we would expect (according to the spillover theory) that the individual's role at work may be affected. The divorce may have a negative effect in that he or she might not be able to think clearly while at work. On the other hand, an individual trained in a variety of management techniques at work may be able to apply some of these skills to his or her parenting practices at home. This would be an example of positive spillover.

2) The Compensatory theory asserts that there is an inverse relationship between work and family (Zedeck \& Mosier, 1990). For example, an individual may be forced to allocate the largest portion of their time toward work, which in turn detracts from the time he or she has available to spend with family. An attempt to offset strain is yet another characteristic of the compensatory theory. For example, an individual that works in a fast-paced, stressful environment may feel the need to avoid stressful situations at home (i.e., household chores, socializing, etc.). The underlying characteristic of the compensatory theory is that an individual will strive to achieve in one domain, that which is missing or lacking in the other domain (Evans \& Bartolome, 1984). 
3) The Segmentation theory asserts that no relationship exists between an individual's roles at work and his or her roles in the family. Due to the time and distance barriers between work and family, individuals can maintain an independent and complete separation of the two domains (Zedeck \& Mosier, 1990).

A further review of work-family literature reveals that the spillover theory has been the most represented and empirically accepted theory involving the work-family interaction (Evans \& Bartolome, 1984; Lambert, 1990; Rousseau, 1978).

In 1977, Joseph Pleck incorporated ideas of the spillover theory into a "work-family role system." In this role system, Pleck suggested that the boundaries between work and family roles are asymmetrically permeable (emotions, attitudes, skills, and behaviors from one domain penetrate the other domain with unequal frequency). In addition, pleck hypothesized that a gender difference exists in the directional flow of the spillover. For females, it was suggested that family demands would interfere with a woman's work role, more so than the reverse. For males, the opposite was suggested so that work demands would commonly interfere with a man's family role, more so than the reverse. 


\section{RECENT RESEARCH}

As organizations are coming face to face with the reality of "work force 2000 " there is a definite need for a better understanding of what factors potentially influence the directionality of individuals' spillover between work and family roles. Employers who believe that family involvement interferes with women's careers are likely "(a) to expect women's performance at work to decline as their family responsibilities increase, (b) to be wary of hiring or promoting women, and (c), perhaps, to view family-supportive policies as having limited payoffs" (Lobel, 1991, p.507). The demographics and values of our society and work force have changed considerably since Pleck's (1977) study. Therefore, it would seem reasonable to assume that the work roles and family roles of males and females have changed as well. Recent research has begun to reflect some contradictions that may indicate a shift has and is occurring in traditional sex roles.

Frone et al. (1992a) described a study conducted by Hall \& Richter (1988) which reported a number of case studies in work-family conflict. From this information Frone et al. (1992a) concluded that individuals consistently reported more spillover into their family lives, regardless of the reporter's gender.

Greenhaus, Parasuraman, Granrose, Rabinowitz, and Beutell 
(1989) examined "dual-career" families for several potential sources of work-family conflict including: demographic information, work salience, task characteristics, work schedules, and role stressors. Results from this study revealed no significant gender differences in the amount of work-family conflict an individual perceives (i.e., once certain demographic and work role characteristics were statistically controlled for).

Frone, Russell, and Cooper proposed a comprehensive work-family model (Appendix A) in their 1992b study. Within this model the variables of Job Involvement and Job Stressors are used as predictors of Work $\rightarrow$ Family conflict, and the variables Family Involvement and Family Stressors are used as predictors of Family $\rightarrow$ Work conflict. An overall goodnessof-fit was assessed for the model in order to test for significant covariation among the model's variables. This was followed by a comparison-of-fit analysis that tested the generalizability of the model on a number of sociodemographic variables (i.e., gender, race, job type). The results of this evaluation brought forth an important finding, there were no significant gender differences found in individuals' reports on work $\rightarrow$ family and family $\rightarrow$ work conflict spillover measures.

Using the same data from their initial 1992 study (i.e., 1992b), Frone et al. (1992a) focused solely upon the fact that 
their data failed to support the gender-based directionality hypothesis set forth by Joseph Pleck (1977). Frone et al. (1992a) concluded that work and family spillover may function in a similar fashion for both men and women.

\section{GOALS OF THIS STUDY}

If gender does not contribute significantly to predicting inter-role conflict (i.e., contending pressures from a number of different roles), then what accounts for the individual differences noted in past literature? Perhaps, the significant spillover differences that were attributed to gender in the past, were really due to contrasting levels of involvement (psychological and behavioral) for men and women.

The degree of psychological and behavioral involvement in one domain has been assumed by many researchers to be one of the best predictors of inter-role conflict within the other domain (Duxbury \& Higgins, 1991; Frone et al., 1992b; Greenhaus \& Beutell, 1985; Greenhaus et al. 1989; Kanungo, 1982; Sekaran, 1983; Yogev \& Brett, 1985).

It is likely that Pleck (1977) was dealing with a more sex-segregated job market where men were in positions that required high levels of job involvement (and thus showed more work->family spillover) and where women were in positions that encouraged high levels of family involvement (thus showed more family->work spillover). Since 1977, however, there has been 
an increased representation of females in the work force, especially in positions that require high levels of job involvement. The number of female managers rose $121 \%$ while the number of male managers rose only $18 \%$ between 1970-1980 (Powell, Posner, \& Schmidt, 1984). It would seem reasonable to conclude that the advancements made in desegregating the work force has, in turn, had an effect on the levels of job and family involvement to which men and women ascribe. A study conducted by Powell et al. (1984) demonstrates drastic changes in job and family involvement.

Powell et al. (1984) conducted a survey of members of the American Management Association (A.M.A). Female members of this organization were expected to report job involvement equal to that of male members of the A.M.A.. Overall results of their study revealed not only an imbalance in reported job involvement, but there was a complete contradiction of traditional sex-role stereotypes. Female managers placed more emphasis on their careers than they did on their families. Male managers, on the other hand, were more willing to sacrifice aspects of their work-role for their family.

Lambert (1990) offers a possible explanation for why women with strong career aspirations deviate from traditional sex-roles :

Jobs which provide meaningful work and offer opportunities for promotion and financial reward usually require extraordinary devotion, which often forces workers to give their families 
less attention than is required for building a satisfying and involving home life. This process is also particularly visible among women workers. It has been observed that women must perform better than men to be promoted, and so when faced with the opportunity for promotion they put more effort into their work, often to the detriment of their personal lives (Lambert, 1990, p.247).

It is the premise of this paper that at one time, gender was a good predictor of how individuals would be affected by inter-role conflict between work roles and family roles. However, with the work force becoming less sex-segregated, gender may no longer be as significant a predictor as it once was. An individual's level of involvement in a given domain, however, has consistently been a significant predictor of inter-role conflict and the direction of spillover.

The different socialization processes that individuals go through may account for a large extent of the individual differences detected in research. Socialization processes help shape an individual's personality, which in turn, lays the groundwork for what roles an individual will perform in life. Thus, an understanding of certain individual personality characteristics (i.e., motivations and values) may help us predict to which domain (work or family) an individual will ascribe the greatest degree of commitment, which in turn will help us to predict how that individual will experience work-family inter-role conflict. 
Although many personality characteristics may have an effect on the level of an individual's involvement in a given domain, two personality constructs were examined in the present study: 1) values associated with the Protestant Work Ethic (e.g., the work orientation scale, of the California Psychological Inventory), and 2) the motivation to be a manager (e.g., the managerial potential scale of the California Psychological Inventory).

The personality construct of work orientation is "the sense of commitment and obligation to work that one finds in persons of exceptionally conscientious, dependable, and selfdisciplined temperament" (Gough, 1985, p.505). On the other hand, Managerial potential is a personality construct that is made up of these characteristics: "self-confidence, cognitive clarity, and goal orientation" (Gough, 1984, p.233). Possession of these personality characteristics have been shown to be important for positions requiring high job involvement (e.g., management). It was the presumption of this study that both of these personality constructs would be indicative of the level of work -> family conflict to which an individual ascribes. 
RESEARCH HYPOTHESES

A synopsis of the literature and discussion presented here reveals seven possible predictors of how an individual will experience inter-role conflict (i.e., between family \& work). These are: 1) an individual's gender; 2) personality constructs related to the motivation to work (work orientation and managerial potential); and 3) the predictor variables used in Frone et al.'s (1992b) model of the work-family interface (e.g., job involvement, family involvement, job stressors, and family stressors; see Appendix A). In order to examine the predictive strength of these seven variables, the following hypotheses were addressed:

\section{Hvpothesis 1}

Job stressors and job involvement will have a significant positive relationship with Work $\rightarrow$ Family conflict. In past research job stressors (Frone et al. 1992b; Greenhaus \& Beutell, 1985; Greenhaus et al. 1989) and job involvement (Duxbury \& Higgins, 1991; Frone et al., 1992b; Greenhaus \& Beutell, 1985; Greenhaus et al. 1989; Kanungo, 1982; Sekaran, 1983; Yogev \& Brett, 1985) have been shown to be significant predictors of "strain-based" and "time based" conflict generating from an individual's work domain. 
Hypothesis 2

Family stressors and family involvement will have a significant positive relationship with Family $\rightarrow$ Work conflict. The positive relationship between family involvement and family generated role conflict has been demonstrated and discussed in a number of studies (Duxbury \& Higgins, 1991; Frone et al., 1992b; Greenhaus \& Beutel1, 1985; Greenhaus et al. 1989; Kanungo, 1982; Sekaran, 1983; Yogev \& Brett, 1985). The specificity of studying the relationship between family stressors and Family -> Work conflict was first examined by Frone et al. (1992b) where a significant positive relationship was found.

\section{Hyoothesis 3}

There will be no significant gender difference in reported inter-role conflict (Work $\rightarrow$ Family \& Family $\rightarrow$ Work). This reflects recent studies' findings (Frone et al., 1992a; Greenhaus et al., 1989; and Hall \& Richter, 1988) and runs contrary to the hypothesis set forth by Joseph Pleck in 1977 .

\section{Hypothesis 4}

The relationship of managerial potential (the motivation to manage), work orientation (work values) and Work -> Family conflict will be such that: 
- There will be a positive and significant relationship between each of these personality constructs and the degree of Work $\rightarrow$ Family conflict an individual experiences.

- There will be a negative and significant relationship between each of these personality constructs and the degree of Family $\rightarrow$ Work conflict an individual experiences.

In other words, the more individuals value work and are motivated to manage, the more Work $\rightarrow$ Family conflict those individuals will experience. On the other hand, individuals possessing strong work values and who are motivated to manage will also report less Family $\rightarrow$ Work conflict. This hypothesis seeks to determine whether or not an individual's personality characteristics predict his or her level of reported role conflict. Similarly to the gender hypothesis, simple main effects are predicted.

\section{Hvoothesis 5}

Frone et al. (1992b) demonstrated that job involvement and job stress have a significant positive relationship with Work -> Family conflict. Pleck (1977) believed that gender had a significant main effect on Work $\rightarrow$ Family conflict. The premise of this study is that Managerial Potential and Work Orientation will each have a significant positive relationship 
with Work -> Family conflict. Therefore, Hypothesis \#5 will assess all of these variables (with the addition of Family Involvement and Family Stressors) simultaneously in order to detect which variables have the strongest positive relationships with Work $\rightarrow$ Family conflict (see Appendix B). Specifically, Hypothesis \#5 predicts that the strongest relationships with Work $\rightarrow$ Family Conflict will involve the variables of job stress, managerial potential, and work orientation. 


\section{METHODS}

\section{SUBJECTS}

Subjects for the proposed study consisted of employees from a department of a civil service agency. A letter briefly describing the voluntary nature of the study was sent out two weeks prior to the actual study. Questionnaires with cover letters (describing the purpose of the study and guaranteeing anonymity) were sent out to all 300 individual employees via the company's internal mail system.

The goal of this study was to obtain a $50 \%$ return rate and thus a final sample of approximately 150 individuals. The final sample consisted of 134 individuals (a return rate of $45 \%$ ).

\section{INSTRUMENTS}

A questionnaire was used in the present study which assessed the following areas: demographic information, the direction of inter-role conflict (work $\rightarrow$ family, family $\rightarrow$ work), job and family stressors, job and family involvement, Managerial Potential and Work Orientation (see Appendix C) . All scales utilized in this study were identical to those used in Frone et al., (1992a\&b), with the exception of the 
Managerial Potential scale and the Work Orientation scale.

\section{Directional scale for work-family conflict}

The direction and degree of spillover were assessed by four questions developed by Frone, Russell, \& Cooper (1992). The first two questions assessed the degree to which an individual's work interferes with his or her family life (W-$>F$; the coefficient alpha reported was .76). The two questions were: "How often does your job or career interfere with your responsibilities at home, such as yard work, cooking, cleaning, repairs, shopping, paying the bills, or child care?" and "How often does your job or career keep you from spending the amount of time you would like to spend with your family?" (see items 1-2 of the questionnaire contained in Appendix C) .

The second set of questions assessed the degree to which an individual's family life interferes with his or her work life $(F-->W$; alpha $=.56)$. These two questions were: "How often does your home life interfere with your responsibilities at work, such as getting to work on time, accomplishing daily tasks, or working overtime?" and "How often does your home life keep you from spending the amount of time you would like to spend on job or career-related activities?" (see items 3-4, Appendix C) .

For each item a five-point response scale was provided 
(1=almost never, 2=occasionally, 3 =about half the time, $4=$ frequently, 5=almost always ) .

In Frone et al.'s (1992b) study these four questions were examined via a principle component analysis. The analysis revealed two factors with eigenvalues greater than 1.0 and small cross-factor loadings.

\section{Job Involvement}

Job involvement is a measure of how central an individual's career or work is to his or her self-image or self-concept (Kanungo, 1982). The Lodahl \& Kejner's (1965) scale of job involvement is generally the most widely used job involvement scale, but a study conducted by Blau (1985) established that the revised Kanungo (1982) job involvement scale is superior in its assessment of a uni-dimensional construct (i.e., the Kanungo job involvement scale does a better job of eliminating confounding constructs and thus results in a purer measure of job involvement).

The Job Involvement scale used in this study consisted of eight questions based on Kanungo's 1982 work (internal consistency $=.87$; test-retest $=.85)$. Each item provided a six-point agree/disagree response scale (see items 21-28). 
Job Stressors

The Job Stressors scale measured an individual's level of stress at work. This strain-based conflict has been demonstrated in the past to be a good indicator of work conflict, work $\rightarrow$ family conflict, and overall work-family conflict (Duxbury \& Higgins, 1991; Frone et al, 1992b; Greenhaus \& Beutell 1985; Greenhaus et al., 1989; Shamir, 1983).

The Job Stressor scale contained 20 items taken from a scale used in Frone et al. 's 1992 (a) study (see items 29-48). Three dimensions of job stress were assessed: lack of autonomy (6 items), role ambiguity ( 6 items), and work pressure (8 items; Frone et al., 1992b).

Job Stressor items were responded to on a four-point response scale (reporting frequencies). Responses to all items were combined for an overall job stressor score.

\section{Family Involvement}

Family involvement is a measure of how central an individual's family is to his or her self-image or selfconcept. For this measure, the wording of five items from the Kanungo (1985) Job Involvement scale were adapted so that they would apply to issues of family involvement, rather than job involvement.

For example, the Job Involvement item "I am very much 
personally involved in my job" was modified to read "I am very much involved personally with my child(ren)." This procedure was cited as being successful in previous work-family research (Frone et al., 1992b).

The Family Involvement scale measured two realms of family involvement: 1) Parental involvement (see items 49-53); and 2) Marital involvement (see items 54-58).

Response scales were designed in the same manner as those for the Job Involvement scale (six-point agree/disagree response scale).

Family involvement scores were calculated as follows:

1) Overall Family involvement scores were an average of all ten items for individuals who were both married and parents (items 49-58).

2) Overall Family involvement scores were an average of the five "Parental involvement" items for individuals who were not married, but had children (items 49-53 only).

3) Overall Family involvement scores were an average of the five "Marital involvement" for individuals who were married, but had no children (items 53-58 only).

Mean scores for this scale were computed only for items that were relevant to the individual (i.e., in accordance with the demographic information provided). Items of the scale that did not apply to the individual were considered not applicable (see instructions for each portion of the Family Involvement scale). 


\section{Family Stressors}

The Family Stressor scale measured stress generated from within that individual's family domain. Family stress has been demonstrated in the past to be an indicator of family conflict, family $\rightarrow$ work conflict, and overall work-family conflict (Duxbury \& Higgins, 1991; Frone et al, 1992b; Greenhaus \& Beutell, 1985).

The Family stressor scale contained a total of eight items also used in Frone et al.'s 1992 (a) study. The eight items focused upon two family dimensions: 1) Parental stressors (4 items); and 2) Marital stressors (4 items).

All four Parental stressor items (see items 59-62) and the first three items of the Marital stressor scale (see items 63-65) were responded to on four-point response scales (reporting frequencies). The final item on the Marital stressor scale (see item 66) was responded to on a five-point scale (reporting frequencies). Overall family stressor scores were calculated as follows:

- An average of all eight items for respondents who were both married and have children.

- An average of the four marital stressor items for respondents who were married, but had no children (i.e., all items applicable to this portion of the sample).

- An average of the four parental stressor items for respondents who had children, but were not married (i.e., all items applicable to this portion of the sample).

Mean scores for this scale were computed only for items 
that were relevant to the individual (i.e., in accordance with the demographic information provided). Items of the scale that did not apply to the individual were considered not applicable (see instructions for each portion of the Family Stressors scale).

\section{Managerial potential}

Managerial Potential (Mp) is a sub-scale measure, derived from the California Psychological Inventory (CPI), that represents managerial competence and interests (Gough, 1987). In a review of previous attempts at Managerial Potential scales, Gough (1984) isolated 34 items from the CPI that correlated significantly with managerial competence and interest. These 34 items now make up the Managerial potential scale (items 67-136 are intermixed and assess both Managerial Potential and Work orientation).

Gough (1984) described the Managerial Potential scale as being "diagnostic of behavioral effectiveness, selfconfidence, cognitive clarity, and goal orientation, for both sexes, with no implications for self-centeredness or exploitative tendencies (p.233)."

Individuals' responses to $\mathrm{Mp}$ items were made by indicating whether they agreed or disagreed with the statement provided. Subjects were given one point for every item they responded to correctly, according to an Mp answer key (Gough, 
1984).

Work Orientation

In 1982 Kanungo made a point of distinguishing work orientation from job involvement. According to Kanungo, an individual with a high work orientation (sometimes referred to as the Protestant Work Ethic) does not necessarily experience high job involvement (the reverse being true as well). Work Orientation (Wo) is another sub-scale derived from the California Psychological Inventory (CPI) (Gough, 1987). The Work Orientation scale seeks to measure "the sense of commitment and obligation to work that one finds in persons of exceptionally conscientious, dependable, and self-disciplined temperament" (Gough, 1985, p.505).

The 40 item wo scale was derived by correlating CPI items with measures of job performance and scores obtained from an Adjective Check List (Gough, 1985). Reliability estimates for these measures reported were: alpha $=.75$; and test-retest $=$ .70 .

Individual's responses to the wo scale were made by indicating whether they agreed or disagreed with the statement provided. Like the Managerial Potential scale, subjects were given one point for each correct response (according to a keyed wo answer sheet). 


\section{Demographic Information}

Demographic information collected from the survey included: gender, age, marital status, number of children, age of youngest child, job status, authority within the organization, and job tenure. Except for gender, all demographic items were used for exploratory analyses.

\section{PROCEDURE}

Initial contact with potential subjects was made via a memo sent from their supervisor. The memo consisted of a brief explanation of the study to be conducted, and stressed the fact that the study was voluntary and anonymous.

The survey was mailed through the office mail system to each employee in the department. Included with the questionnaire was a cover letter providing instructions and again briefly describing the study and its voluntary and anonymous aspects. Also included with each questionnaire was a pre-stamped envelope addressed to the Department of Psychology at Portland State University.

\section{ANALYSES}

Hypothesis 1 stated that scores on the Job Stressors scale and the Job Involvement scale will have a significant positive relationship with the Work-Family conflict scale 
measuring work $\rightarrow$ family conflict spillover. A multiple linear regression equation was utilized to assess the relationship between Job Stressors, Job Involvement, and Work $\rightarrow$ Family conflict. The independent variable entered in the first step was Family $\rightarrow$ Work conflict (i.e., to account for the reciprocal relationship between Family $\rightarrow$ Work and Work $\rightarrow$ Family conflict). Independent variables entered on the second step were as follows: $X(1)=$ Job stressors, $X(2)=$ Job Involvement, $X(3)=$ Family stressors, and $X(4)=$ Family Involvement. The dependent variable ( $Y$ ) in this equation was Work -> Family conflict. Hypothesis \#1 would be supported if semi-partial correlation coefficients are significant for both Job Stressors and Job Involvement.

Hypothesis 2 stated that scores on the Family Stressors scale and the Family Involvement scale will have a significant positive relationship with the Work-family conflict scale measuring Family $\rightarrow$ Work conflict spillover. Again, a multiple linear regression equation was utilized to assess the relationship between Family Stressors, Family Involvement, and Family $\rightarrow$ Work conflict. The first step entered Work $\rightarrow$ Family conflict (i.e., to account for any covariance between Work $\rightarrow$ Family and Family $\rightarrow$ Work conflict). Independent variables in the second step of the equation were as follows: $X(1)=$ Family Stressors, $X(2)=$ Family Involvement, $X(3)=$ Job Stressors, and $\mathrm{X}(4)=$ Job Involvement. The dependent variable 
$(Y)$ in this equation was Family $\rightarrow$ Work conflict. Hypothesis \#2 would be supported if semi-partial correlation coefficients are significant for both Family Stressors and Family Involvement.

Hypothesis 3 stated that there will be no significant gender difference in reported inter-role conflict (Work $\rightarrow$ Family \& Family $\rightarrow$ Work). A multiple linear regression equation was utilized to assess hypothesis \#3. The dependent variable for the first equation was Work $\rightarrow$ Family conflict. The first step entered Family $\rightarrow$ work conflict in order to account for the shared variance between the Work $\rightarrow$ Family and Family $\rightarrow$ Work Conflict measures. The second step entered gender (i.e., dummy coded males $=0$, and females $=1$ ). A second regression equation was computed using the same procedure as above, but the dependent variable was Family -> Work conflict. Hypothesis \#3 would be supported if Gender failed to contribute significantly to both work $\rightarrow$ Family conflict and Family $\rightarrow$ Work conflict.

Hypothesis 4 stated that each of the personality measures (i.e., Managerial Potential and Work Orientation) will have a positive relationship with scores on the Work $\rightarrow$ Family conflict scale. Hypothesis 4 also stated that each of the personality measures (i.e., Managerial potential and work Orientation) will have a negative relationship with scores on the Family $\rightarrow$ Work conflict scale. 
zero-order correlation coefficients were computed to assess the relationships between Managerial Potential, Work orientation, and Work $\rightarrow$ Family conflict. Zero-order correlation coefficients were also computed to assess the relationships between Managerial Potential, Work Orientation, and Family $\rightarrow$ Work conflict.

Hypothesis \#4 would be supported if correlation coefficients, for the given relationships, are in the predicted direction and significant.

Hypothesis 5 stated that three variables (i.e., Job Stressors, Managerial Potential, and Work Orientation) will have positive relationships with Work -> Family conflict.

Multiple linear regression was applied to assess these relationships. In the first step Family $\rightarrow$ Work conflict was entered. Independent variables entered on the second step were as follows: $X(I)=$ Job Stressors, $X(2)=$ Job Involvement, $\mathrm{X}(3)=$ Gender, $\mathrm{X}(4)=$ Managerial Potential, $\mathrm{X}(5)=$ Work Orientation, $X(6)=$ Family Stressors, and $X(7)=$ Family Involvement. The dependent variable in this equation was $Y(1)$ $=$ Work $\rightarrow$ Family conflict. Independent variables entered in the second step were blocked and entered simultaneously.

Hypothesis \#5 would be supported if Managerial Potential, Work Orientation, and Job stressors are significant semipartials. 


\section{RESULTS}

\section{DESCRIPTIVE STATISTICS}

The sample used for this study consisted of 134 participants with a mean age of 44 years. Subjects were $56 \%$ male, with $76 \%$ reporting to be "married or living as married." 65\% of the sample reported having children. Ages of the children ranged from 1 to 39, with a mean age of 15 years. Approximately $70 \%$ of the subject pool works 40 hours or more a week, while another $28 \%$ works between 30-40 hours a week. Managerial levels were well distributed with $66 \%$ of the sample being non-management $(N=89), 23 \%$ first-level managers (i.e. supervisory responsibilities, but subordinates are not managers) $(\mathrm{N}=31)$, and $9 \%$ second-level managers (i.e. supervisory responsibilities and subordinates are managers as well) $(N=12)$. The mean number of years employed within this organization was approximately 11.

Table I is a comparison of descriptive statistics for the scales that were used both in this study and the Frone et al. 1992b study. The largest difference exists between the two Job Involvement scores. Subjects in this study tended to report lower levels of job involvement than did subjects in Frone et al.'s study (1992b). 
TABLE I

A COMPARISON OF MEANS AND STANDARD DEVIATIONS FOR SCALES USED IN THIS STUDY AND FRONE ET AL.'S 1992b STUDY

\begin{tabular}{|c|c|c|}
\hline \multirow{2}{*}{ WARD: } & $M$ & $S D$ \\
\hline & & \\
\hline Work $\rightarrow$ Family Conflict* & 2.53 & 1.08 \\
\hline Eamily $\rightarrow$ Work Conflict* & 1.57 & 0.63 \\
\hline Job Involvement* & 2.62 & 1.05 \\
\hline Job Stressors** & 2.18 & 0.38 \\
\hline Family Involvement $* \star \star$ & 4.94 & 0.77 \\
\hline 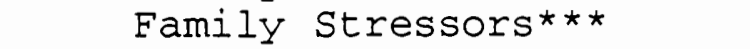 & 1.89 & 0.46 \\
\hline ERONE et al. (1992b): & & \\
\hline Work $\rightarrow$ Family Conflict & 2.21 & 1.07 \\
\hline Family $\rightarrow$ Work Conflict & 1.39 & 0.61 \\
\hline Job Involvement & 3.92 & 1.18 \\
\hline Job Stressors & 2.05 & 0.36 \\
\hline Family Involvement & 5.14 & 0.79 \\
\hline Eamily Stressors & 1.83 & 0.49 \\
\hline
\end{tabular}

$\star N=134 \quad * * N=133 \quad * \star * N=120$

Table II reports the reliability estimates for the scales used in this study. Alpha coefficients reported for the same scales in Frone et al. (1992b) are also listed for comparison. Both the Family Stressor and Job Stressor Scales demonstrated lower alpha coefficients than did the Frone et al. (1992b) results. All other scales showed equal or greater reliability compared to the Frone et al. (1992b) sample.

Table III summarizes the intercorrelations between the scales used in this study. The intercorrelations found in this study are similar to those found in Frone et al. 1992b. 
TABLE II

A COMPARISON OF RELIABILITY ESTIMATES FOR SCALES USED IN THIS STUDY AND FRONE ET AL.'S 1992b STUDY

\begin{tabular}{llll}
\hline Scales & \multicolumn{3}{c}{ Alpha Coefficients } \\
& $\mathrm{N}=$ & WARD & FRONE et al. \\
Work -> Family Conflict & 132 & .85 & .76 \\
Family -> Work Conflict & 134 & .64 & .56 \\
Job Involvement & 131 & .87 & .88 \\
Job Stressors & 130 & .68 & .72 \\
Family Involvement & 77 & .88 & .88 \\
Family Stressors & 77 & .54 & .66 \\
\hline
\end{tabular}

TABLE III

INTERCORRELATION MATRIX FOR SCALES

\begin{tabular}{lllllllll}
\hline Scales & 1 & 2 & 3 & 4 & 5 & 6 & 7 & 8 \\
\hline
\end{tabular}

1. W->F Conf. 1.0

2. $\mathrm{F} \rightarrow>$ W Conf. $.30 * 1.0$

3. Job Invol. $\quad .15 \quad .17 \quad 1.0$

4. Job Stress. .28* $.33 \star * .08 \quad 1.0$

5. Fam. Invol. $\quad .04-.22-.07 \quad-.08 \quad 1.0$

6. Fam. Stress. $.24 * \quad .41 * * .18 \quad .18-.30 * 1.0$

7. Work Orient. $-.27 *-.11-.09-.30 * * .11-.24 * 1.0$

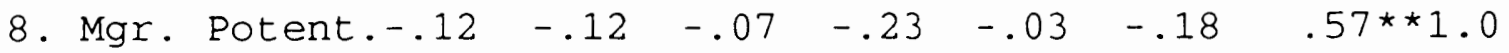

2-tailed significance: *.01 ** .001 $\mathrm{N}=119$

TESTS OF HYPOTHESES

Hypothesis 1

Hypothesis 1 predicted that scores on the Job Involvement and Job Stressors scales would be significant positive predictors of Work $\rightarrow$ Family conflict as measured by the Frone 
et al. (1992b) scale. Table IV summarizes the multiple regression equation used for Hypothesis 1. The Multiple R was .41 and the equation accounted for $16 \%$ of the variance in Work $\rightarrow$ Family Conflict, $\underline{\mathbf{F}}(5,113)=4.445, \underline{\mathrm{p}}<.001$. Hypothesis 1 was only partially supported. Job Involvement scores were not significant predictors of Work $->$ Family conflict (Beta = .080), however, Job Stressor scores were significant. It is interesting to note that the covariation between the Work -> Family and Family $\rightarrow$ work scales did not reach the significance level of $\underline{p}<.05$. The presence of job stress was the best single predictor in the equation and had a beta of $.191, \underline{\mathrm{p}}<.05$.

TABLE IV

REGRESSION EQUATION FOR HYPOTHESIS 1: PREDICTING REPORTS OF WORK $\rightarrow>$ FAMILY CONFLICT

Equation:

$\begin{array}{ll}\text { Multiple R } & .405 \\ \text { R Square } & .164 \\ \text { Adjusted R Square } & .127 \\ \quad F=4.445 & p^{<.001}\end{array}$

Variables in the Equation:

$\begin{array}{lrlll} & \text { B } & \text { Beta } & \text { T } & \begin{array}{l}\Delta \text { in } R \\ \text { Square }\end{array} \\ \text { F->W Conflict } & .317 & .184 & 1.857 & .087 * * * \\ \text { Job Involvement } & .085 & .080 & .911 & .078 * \\ \text { Fam. Involvement } & .208 & .147 & 1.627 & \\ \text { Job Stressors } & .551 & .191 & 2.097 * & \\ \text { Fam. Stressors } & .391 & .165 & 1.693 & \end{array}$

${ }^{*} p<.05 \quad * \star * p<.001$ 
In an attempt to explain the mixed results for Hypothesis 1, a follow-up analysis was performed. Individuals for this equation were dummy coded as either working in a managerial role (including first and second-level, coded as $=1$ ), or not (non-management coded as $=0$ ). The resulting variable was simply called Management. Four interaction terms were also created: Job Involvement $x$ Management, Job Stressors $x$ Management, work Orientation $\mathrm{x}$ Management, and Managerial Potential $\mathrm{x}$ Management. The dependent measure for the regression equation was Work $->$ Family Conflict. The covariation between the Work $\rightarrow$ Family and Family -> Work Conflict scales was accounted for by entering Family -> Work Conflict on the first step. The main effects for each of the variables were accounted for by entering the predictor variables (Job Involvement, Job Stressors, Work Orientation, and Managerial Potential) on the second step. The third step of the equation entered the interaction terms defined above. The Multiple $R$ was .47 and the equation accounted for $22 \%$ of the variance in Work $\rightarrow$ Family Conflict, $E(10,120)=3.418$, $\underline{p}<.001$ (see Table V). The most significant predictor was the main effect of Job Stressors with a beta of .252 , $\underline{p}<.01$. The variables of Work Orientation (beta of -.229) and Family -> Work Conflict (beta of .208) were also found to be significant $(\underline{p}<.05)$. The interaction term of Job Involvement $x$ Management, with a beta of .540 , $\underline{p}<.05$, was the only 
interaction term in the model that was found to be significant. The results of these analyses indicate that job involvement was indeed a significant predictor of work $\rightarrow$ Family Conflict for first and second-level managers, but not for non-management.

TABLE V

REGRESSION EQUATION FOR FOLLOW-UP ANALYSIS OF JOB INVOLVEMENT

D.V. = Work $\rightarrow$ Family Conflict

Equation \#1 Model Including Job Involvement $\mathrm{x}$ Management

$$
\begin{array}{llr}
\text { Multiple R } & .471 & \\
\text { R Square } & .222 & \\
\text { Adjusted R Square } & .157 & \\
\quad \mathrm{~F}=3.418 & & \mathrm{p}<.001
\end{array}
$$

Variables in the Equation:

\begin{tabular}{lrrrc} 
& & & & $\begin{array}{l}\Delta \text { in } R \\
\text { Square }\end{array}$ \\
Family -> Work Confl. & .350 & .208 & $2.441 *$ & $.065 * *$ \\
Job Involvement & -.071 & -.070 & -.697 & $.098 *$ \\
Job Stressors & .710 & .252 & $2.596 * *$ & \\
Work Orientation & -.059 & -.229 & $-1.971^{*}$ & \\
Managerial Potential & .002 & .006 & .053 & \\
Management & -3.411 & -1.506 & -1.377 & \\
Job Inv. x Management & .423 & .567 & $2.379 *$ & .059 \\
Job Stress. x Management & -.336 & -.330 & -.588 & \\
Work Orient. x Management & .039 & .559 & .646 & \\
Mgmt. Potent. x Management & .069 & .746 & 1.057 & \\
\hline
\end{tabular}

$\star p<.05 * \star p<.01$ 
Hypothesis 2

s.

Hypothesis 2 predicted that scores on the Family Involvement and Family stressors scales would have a significant positive relationship with the dependent variable of Family $->$ work Conflict. Table VI summarizes the findings from the multiple regression equation used to assess Hypothesis 2. The Multiple $R$ was .52 and the equation accounted for $27 \%$ of the variance in Family $\rightarrow$ work confict, $\underline{E}(5,113)=8.294, \underline{p}<.001 . \quad$ Hypothesis 2 received partial support as once again, involvement (i.e., family involvement) was not a significant predictor (Beta $=-.117$ ), but stress (i.e., family stress) was a significant predictor of Family -> Work Conflict with a beta of $.281, \mathrm{p}<.01$. An unanticipated finding was the fact that the Job Stressors scale was also a significant predictor of Family $->$ Work Conflict, with a beta of $.219, \underline{p}<.01$. The covariation between the Family -> Work and Work $\rightarrow$ Family scales, again, did not reach significance at the $\mathrm{p}<.05$ level.

\section{Hypothesis 3}

The purpose of Hypothesis 3 was to assess the main effect that Gender has on the dependent measures of Work $\rightarrow$ Family and Family $\rightarrow$ work Conflict spillover. Specifically, Hypothesis 3 predicted that Gender would not have a significant main effect on the inter-role conflict measures. 
TABLE VI

REGRESSION EQUATION FOR HYPOTHESIS 2: PREDICTING REPORTS OF FAMILY $\rightarrow>$ WORK CONFLICT

Equation:

$\begin{array}{ll}\text { Multiple R } & .518 \\ \text { R Square } & .269 \\ \text { Adjusted R Square } & .236 \\ & 0.001\end{array}$

Variables in the Equation:

$\begin{array}{lcccc} & \mathrm{B} & \text { Beta } & \mathrm{T} & \begin{array}{c}\Delta \text { in } \mathrm{R} \\ \text { Square }\end{array} \\ \text { W->F Conflict } & .093 & .161 & 1.857 & .087 * \star \star \\ \text { Fam. Involvement } & -.096 & -.117 & -1.380 & .182 * \star \star \\ \text { Job Involvement } & .042 & .067 & .818 & \\ \text { Job Stressors } & .366 & .219 & 2.588 * \star & \\ \text { Fam. Stressors } & .386 & .281 & 3.170 * \star & \end{array}$

$\star \star p<.01 \quad \star \star \star p<.001$

Table VII summarizes the multiple regression equations used to assess this Hypothesis. In the first regression equation the dependent variable was work -> Family Conflict. The Multiple $\mathrm{R}$ was .26 and accounted for $7 \%$ of the variance in Work -> Family Conflict $(\underline{F}(2,130)=4.789, \underline{p}<.01)$. The second regression equation used Family $\rightarrow$ Work Conflict as the dependent variable. The Multiple $R$ was .24 and the equation accounted for $6 \%$ of the variance in Family $->$ Work Conflict $(\underline{E}(2,130)=3.935, \underline{p}<.05)$. In each case the significance levels of the equations were due entirely to the shared variance between the Family $\rightarrow>$ Work and Work $->$ Family measures, with betas $=.234 \& .236$, respectively $(\underline{p}<.01)$. Gender did not 
have a significant main effect in either equation, therefore, Hypothesis 3 is accepted.

TABLE VII

REGRESSION EQUATIONS FOR HYPOTHESIS 3: TESTS OF GENDER AS A PREDICTOR OF INTER-ROLE CONFLICT

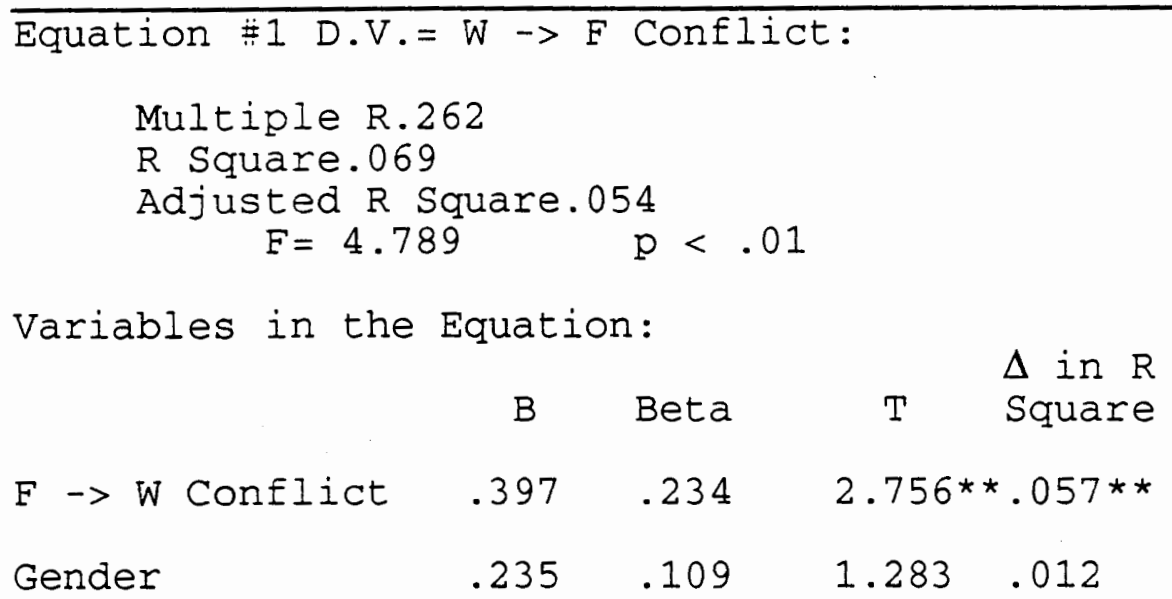

Equation $\stackrel{\# 2}{ }$ D.V. $=F \rightarrow W$ Conflict:

Multiple R.239

$R$ Square. 057

Adjusted R Square.043

$$
F=3.935 \quad P<.05
$$

Variables in the Equation:

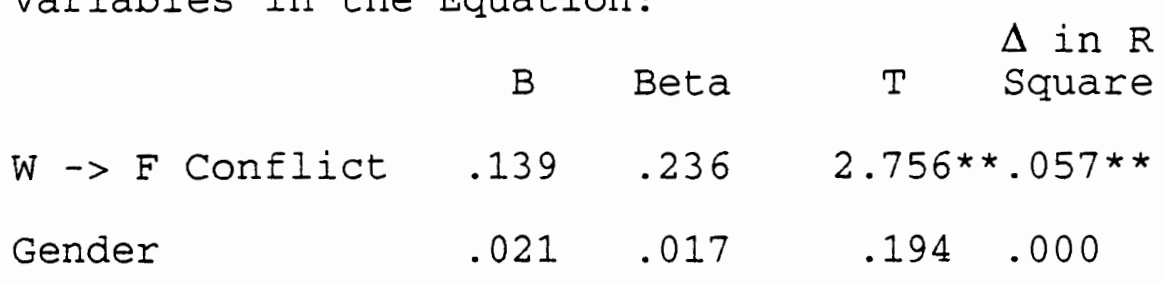

$\star \star p<.01$

Hypothesis 4

The purpose of Hypothesis 4 was to assess the relationship of two personality measures (i.e. Work Orientation and Managerial Potential) with the dependent measures of Family $\rightarrow>$ Work and 
Work $\rightarrow$ Family Conflict spillover. More specifically, Hypothesis 4 predicted that there would be a significant positive relationship between scores on the Managerial Potential scale, the Work Orientation scale and scores on the Work $\rightarrow$ Family conflict scale. In addition, it was hypothesized that there will be a significant negative relationship between scores on the Managerial Potential scale, the Work Orientation scale and scores on the Family $->$ Work Conflict scale. Table VIII shows the zero-order correlations between these measures. These results indicate that regardless of the dependent measure (i.e., $W \rightarrow F$ or $F \rightarrow W$ conflict) the correlation coefficients are negative, and only the relationship between the Work Orientation scale and Work $>$ Family Conflict is significant. Therefore, all of the predicted relationships in Hypothesis 4 are rejected.

\section{TABLE VIII}

ZERO-ORDER CORRELATIONS FOR HYPOTHESIS 4: TESTING THE RELATIONSHIP BETWEEN MOTIVATIONAL VARIABLES AND INTER-ROLE CONELICT

$\begin{array}{lll} & \text { Work->Family } & \text { Family-> Work } \\ \text { Mgr. Potential } & -.116 & -.108 \\ \text { Work Orientation } & -.253 * & -.082\end{array}$

2-Tailed Significance: $*<.01 \quad \mathrm{~N}=133$ 
Hypothesis 5

Hypothesis 5 assessed the contribution of seven variables (i.e., Work Orientation, Managerial Potential, Gender, Job Involvement, Job Stressors, Family Involvement, and Family Stressors) to the prediction of work $\rightarrow$ Family Conflict. Specifically, Hypothesis 5 predicted that Managerial potential, work orientation, and Job stressors will all be significant predictors of Work $\rightarrow$ Family conflict, when all variables are entered into the equation simultaneously. Table IX summarizes the regression equation used to test Hypothesis 5. The Multiple $R$ was .453, and accounted for $21 \%$ of the variance in Work $->$ Family Conflict. Therefore, adding the individual difference variables (i.e., Work Orientation and Managerial potential) to the model used in Hypothesis 1 resulted in a modest increase in the amount of explained variance within Work $\rightarrow$ Family conflict (c.f., Multiple $\mathrm{R}=$ .405, R square $=.16$, from Table IV). Work orientation was the only predictor among the seven variables that was significant (Beta $=-.215, \underline{p}<.05)$, however, it should be noted that the observed relationship between Work Orientation and the dependent variable was negative (i.e., the higher an individual's work Orientation, the less likely he or she is to report work interfering with family). Again, Gender did not make a significant contribution as a main effect. Due to the fact that Managerial Potential (Beta $=.106$ ) and Job Stressors 
$($ Beta $=.164)$ were non-significant, Hypothesis 5 only receives partial support with Work Orientation being significant.

\section{TABLE IX}

REGRESSION EQUATION FOR HYPOTHESIS 5: A TEST OF MOTIVATIONAL VARIABLES AS PREDICTORS OF WORK $\rightarrow$ FAMILY CONFLICT

Equation:

$\begin{array}{ll}\text { Multiple R } & .453 \\ \text { R Square } & .205 \\ \text { Adjusted R Square } & .147 \\ \text { F }=3.522 & p<.001\end{array}$

Variables in the Equation:

$\begin{array}{lcccc} & \text { B } & \text { Beta } & \mathrm{T} & \begin{array}{c}\Delta \text { in R } \\ \text { Square }\end{array} \\ \text { F }>\text { W Conflict } & .321 & .187 & 1.881 & .084 \text { * } \\ \text { Gender } & .192 & .088 & .994 & .121 \text { * } \\ \text { Mgr. Potential } & .032 & .106 & 1.001 & \\ \text { Job Involvement } & .073 & .069 & .783 & \\ \text { Fam. Involvement } & .217 & .155 & 1.691 & \\ \text { Job Stressors } & .470 & .164 & 1.722 & \\ \text { Family Stressors } & .351 & .149 & 1.502 & \\ \text { Work Orientation } & -.057 & -.215 & -1.945 * & \end{array}$

${ }^{\star} \mathrm{p}<.05 \quad \star \star \mathrm{p}<.01$ 


\section{DISCUSSION}

The present study has been guided by three underlying purposes: 1) To test how well involvement (i.e., job involvement and family involvement) and stress (i.e., job stressors and family stressors) predict inter-role conflict (i.e., work $\rightarrow$ family \& family $\rightarrow$ work conflict); 2) To test whether or not gender has a significant main effect on the measures of Work $\rightarrow$ Family and Family $\rightarrow$ Work Conflict; and 3 ) To assess the potential of using individual difference factors (i.e., work motivations) as predictor variables of Work $\rightarrow$ Family and Family $\rightarrow$ Work conflict.

\section{DISCUSSION OF HYPOTHESES}

\section{Hypothesis 1}

Hypothesis 1 stated that job involvement and job stressors would be significant predictors of work $\rightarrow$ family conflict. The results reported in Table IV indicate that this hypothesis was only partially supported. Responses on the Job Stressors scale were shown to have been significant predictors of Work -> Family Conflict, such that individuals reporting high amounts of stress from their job, are more likely to report higher levels of work interfering with their family. This finding lends further support to the notion set forth in 
previous literature (Frone et al., 1992b; Greenhaus \& Beutell, 1985; Greenhaus et al., 1989; Kanungo, 1982; Sekaran; 1983; Yogev \& Brett, 1985) that job stress often leads to inter-role conflict (reflected in this study by the work $\rightarrow$ Family Conflict scale).

A somewhat surprising result, however, was the fact that job involvement was not a significant predictor of Work $\rightarrow$ Family conflict. The same finding was reported by frone et al. (1992b). In conducting several follow-up analyses, Frone et al. (1992b) discovered that job involvement was indeed a significant predictor of work $\rightarrow$ family conflict for whitecollar workers, but not for blue-collar workers. The sample for the present study was made up entirely of white-collar workers, and thus (based upon the follow-up analyses of Frone et al.'s 1992b study) the hypothesized relationship was a significant positive one.

Follow-up assessments were also conducted in the present study to help explain the non-significance of job involvement, but rather than grouping individuals as white or blue-collar, the present study dummy coded individuals as non-management (dummy code $=0$ ) or management (including both first and second-level managers, dummy code $=1$ ). The results of these analyses indicated that job involvement was indeed a 
significant predictor of Work -> Family Conflict for first and second-level managers, but not for non-management (see Figure 1).

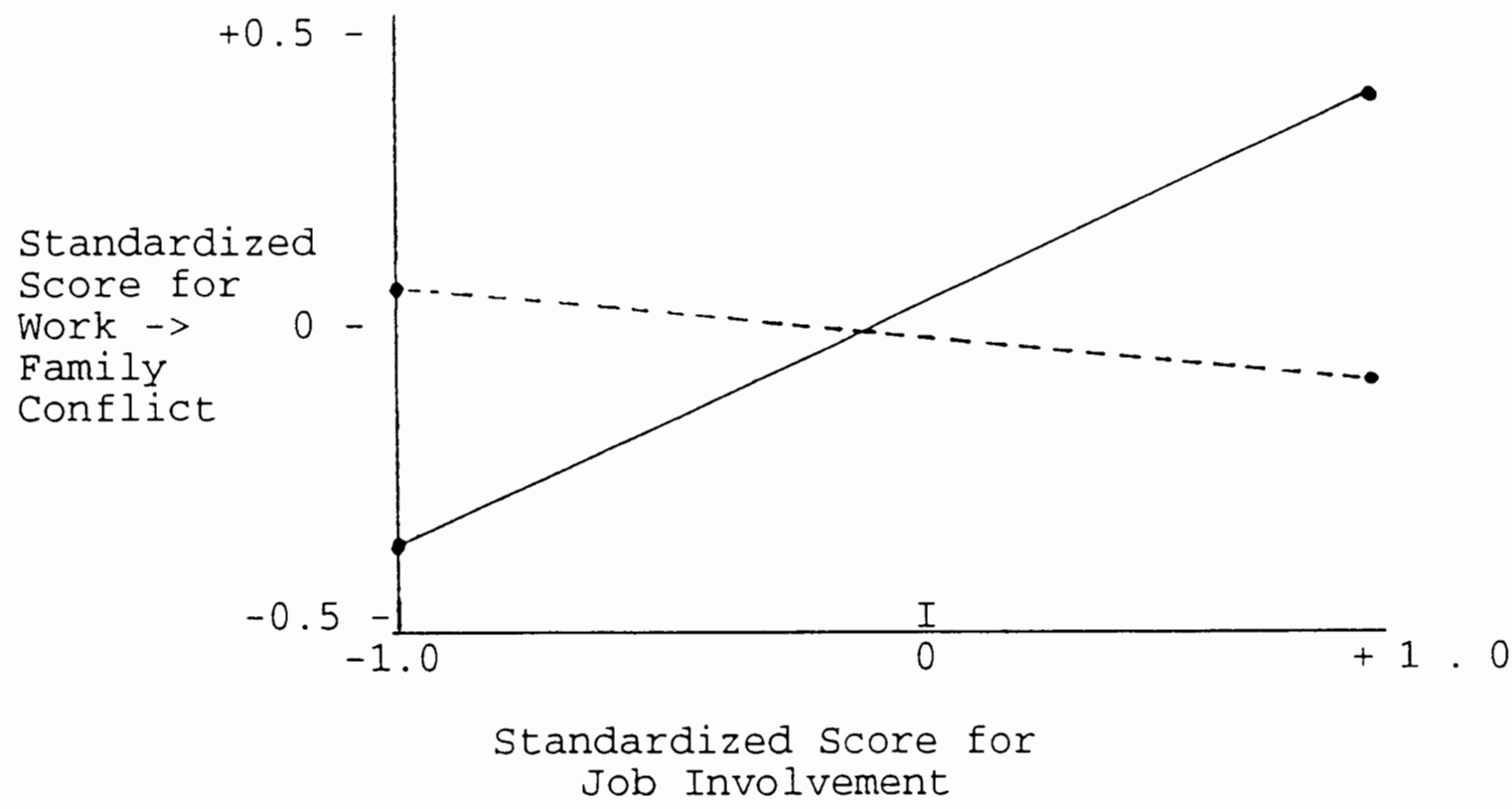

Management $=\longrightarrow \quad$ Non-Management $=-\cdots--\infty$

Figure 1. The Relationship Between Management and Job Involvement.

These results are similar to those found in Frone et al.'s (1992b) study, but one important clarification has been made. Frone et al.'s findings indicated that the significance of the relationship between job involvement and Work -> Family Conflict is dependant upon whether an individual is a white or blue-collar worker. The present study has found that the distinction between white and blue-collar needs to be further differentiated in order for job involvement to be found 
significant in predicting work $\rightarrow$ Family Conflict. The differentiation utilized in the present study was whether or not an individual held a managerial position, which lead to the results mentioned above and portrayed in figure 1 .

Another note to be made in regards to Job Involvement is that individuals in the present study's sample reported lower levels of Job Involvement than those in Frone et al.'s (1992b) study (see Table I). A possible explanation for the lower levels of job involvement could be the fact that individuals in this sample have a high degree of job security in working for a federal agency (further supported by the mean tenure at this organization of 11 years). It is possible that individuals feeling secure in their jobs, may involve themselves less than individuals who must continually prove their worth to an organization in fear of being replaced.

\section{Hypothesis 2}

Hypothesis 2 stated that family involvement and family stressors would be significant predictors of Family $\rightarrow$ Work Conflict. The results reported in Table $\mathrm{V}$ indicate that Hypothesis 2 received partial support. The predictor variable of Family Involvement had a negative relationship with Family -> Work Conflict and was not significant. This finding runs contrary to traditional findings in work-family literature (Duxbury \& Higgins, 1991; Frone et al., 1992b; Greenhaus \& 
Beutell, 1985; Greenhaus et al., 1989; Kanungo, 1982; Sekaran, 1983; Yogev \& Brett, 1985). In these previous works, family involvement has consistently been found to have a positive relationship with family $\rightarrow$ work conflict. In comparing the Family Involvement scale results obtained in this study, to those found in Frone et al.'s (1992b) study (see Tables I \& II of this study) it is difficult to find an explanation for such a vast difference in results. Demographic information (i.e., in regards to age and family make-up) is similar as well, thus this finding may be worthy of further investigation in the future.

The variable of Family Stressors was found to have been a significant predictor of Family $\rightarrow$ Work Conflict. The relationship between these variables was first examined by Frone et al. (1992b), where a positive relationship was established. A positive relationship was also found in the present study, which further confirms Frone et al.'s (1992b) finding.

In addition to Family Stressors, Job Stressors were also found to be significant predictors of Family $\rightarrow$ Work Conflict. This was an unexpected result that perhaps further demonstrates the reciprocity between Family $\rightarrow$ Work and Work $>$ Family conflicts. The separation of these measures (i.e., as opposed to one universal construct of a combined workfamily conflict) is indeed important for further insight into 
the dymamics between work and family, however, one must always keep in mind the intercorrelation between these two domains. However, if the reciprocity between work $\rightarrow$ family and family $\rightarrow$ work is used to help explain why Job stressors are significant, we must wonder why Family stressors were not significant predictors of Work -> Family Conflict. Some light may be shed upon this question when we consider the degree to which work interferes with family. When work $\rightarrow$ family and family $\rightarrow$ work spillover have been measured in past literature, it has been shown that individuals tend to report more spillover from work $\rightarrow$ family. Therefore, the significance of Job Stressors as predictors of family $\rightarrow$ work conflict may simply be a reflection of this higher degree of interference from work.

Hypothesis 3

Hypothesis 3 stated that Gender would not be a significant predictor of Work $\rightarrow$ Family and Family $\rightarrow$ Work Conflict. The results reported in Table VI clearly indicate that there was no significant gender difference found, therefore, Hypothesis 3 was accepted. Gender differences in Work $\rightarrow$ Family and Family $\rightarrow$ Work Conflict were directly tested via a simple t-test as well. There were no significant gender differences found for either Work $\rightarrow$ Family or Family $>$ Work Conflict $(\underline{t}=-1.37$ and $\underline{t}=-.51$, respectively). These 
findings further confirm what several researchers (Frone et al., 1992a\&b; Greenhaus et al., 1989; Hall \& Richter, 1988) have been discovering, the fact that gender appears not to be a significant predictor of inter-role conflict (i.e., work -> family or family $\rightarrow$ work). This finding also adds further evidence against Joseph Pleck's 1977 hypothesis, that gender itself has a significant main effect on work $->$ family and family $\rightarrow$ work conflict spillover. Much of the transition in gender's significance level is probably attributable to the progress organizations have made in breaking down the sexsegregated job-market that has existed for so many years.

\section{Hyoothesis 4}

Hypothesis 4 set out to investigate the relationships between the two motivational measures (i.e., Work Orientation \& Managerial potential) and the two types of inter-role conflict (i.e., Work $\rightarrow$ Family \& Family $\rightarrow$ Work Conflict). Hypothesis 4 predicted that there would be a significant positive relationship between the two motivational measures and Work $\rightarrow$ Family Conflict, and that there would be a significant negative relationship between the two motivational measures and Family $\rightarrow$ Work Conflict. The results of Table VII indicate that Hypothesis 4 was only partially supported since all of the relationships were negative, and only the relationship between Work Orientation and Work $\rightarrow$ Family 
Conflict was significant. As expected, individuals with high levels of work motivation and individuals with a high motivation to manage were more likely to report low levels of family interfering with work, but these same individuals also tended to report lower levels of work interfering with their family. It was thought that individuals ranking highly on these motivational measures would go to great strides to avoid having their family lives interfere with their work. At the same time, it was thought that their motivation to get ahead in the organization could possibly result in their allowing work related issues to interfere with their family lives. However, these findings suggest that perhaps individuals ranking high on these motivational measures are better able to balance the demands of both a career and family, and thus report lower levels of conflict spillover.

\section{Hyoothesis 5}

The goal of Hypothesis 5 was to assess how well each of the seven predictor variables (Gender, Job Involvement, Family Involvement, Job Stress, Family Stress, Managerial Potential and Work Orientation) predicts Work $\rightarrow$ Family Conflict. Hypothesis 5 stated specifically that the variables expected to be found significant would be Job Stress, Work Orientation, and Managerial Potential. The results in Table VIII indicate that only partial support of Hypothesis 5 was obtained. Work 
Orientation was the only variable found to be a significant predictor of Work $\rightarrow$ Family conflict, however, this relationship was found to be a negative one. In other words, individuals with a strong work ethic or high work motivation were less likely to report that their work interferes with their family lives. Although non-significant, the intercorrelation between work $\rightarrow$ family and family $\rightarrow$ work conflict was the second largest predictive variable. Job stress, while also non-significant, accounted for the third largest segment of the explained variance in work $\rightarrow$ Family Conflict. The most significant findings from this portion of the study comes from the fact that the addition of the motivation variables created a modest increase in the amount of explained variance in work -> family conflict and that one of these measures (i.e., Work orientation) was the only predictor variable to reach the $\mathrm{p}<.05$ level of significance. These findings indicate that recognition of individual differences can indeed influence the predictive strength of other variables and help account for some of the variation in inter-role conflict.

In considering the sex-segregated job market of the late 70 's it is not at all unreasonable to suggest that perhaps males and females held different values in that males placed a greater emphasis on work and females placed more emphasis on family. And perhaps these individual differences in work 
motives and values have changed as the job-market has become less sex-segregated. Perhaps as more women moved into the higher levels of organizations their socialization of work values changed as well so that females today are not significantly different from males in how they deal with the conflicting role pressures between work and family. of course this is only one possible explanation and there is no way of knowing just how accurate this explanation is (i.e., since the Managerial Potential \& Work Orientation scales were not developed until the mid $\left.80^{\prime} \mathrm{s}\right)$. However, the present study does tend to add strength to this argument.

\section{THEORETICAL IMPLICATIONS}

The present study assessed the significance of several variables in predicting work $\rightarrow$ family and family $\rightarrow$ work conflict spillover. The variables concerning involvement (i.e., job \& family) and stress (i.e., job \& family) were derived from a conceptual model of the dynamics between work and family, proposed by Frone et al. (1992b). The present study, by no means, refutes the findings in Frone et al. (1992b), however, there were findings in the present study that have theoretical implications. The results from Hypothesis 1 and 2 in the present study indicate that job involvement and family involvement are not strong indicators 
of inter-role conflict. In the present study Job involvement was found to be a significant predictor of Work -> Family Conflict for managers only. This finding is similar to that of Frone et al. (1992b) where Job Involvement was found to be a significant predictor of Work -> Family Conflict for whitecollar workers only. These findings, together, clearly have theoretical implications.

Based upon the theoretical work presented in previous work-family literature, there seems to be a clear relationship between job involvement and work $\rightarrow$ family conflict spillover. However, based on the present study and Frone et al. 's (1992b) findings this relationship was not demonstrated for blue-collar or non-management individuals. Therefore, we must assume one of two things: 1) either the current scales being utilized to measure job involvement are failing to detect involvement for blue-collar/non-management individuals; or 2) the theoretical relationship between job involvement and work $\rightarrow$ family conflict does not hold true for blue-collar/nonmanagement individuals. The first assumption would imply that work-family researchers need to either develop new measures of job involvement or improve upon the current measures of job involvement so that involvement of blue-collar/non-management workers can be examined as well. The second assumption would imply that future theoretical models portraying the relationship between job involvement and work $\rightarrow$ family 
conflict may need to consider the possibility that a moderating variable exists. This moderator should somehow reflect the characteristics of individuals in white-collar positions or perhaps even as specific as individuals in managerial positions.

Based upon the results from the present study and those from Frone et al.'s (1992b) it appears that the most significant predictors used in Frone et al.'s theoretical model are job and family stressors. Another result from the present study that could be theoretically important is the fact that Job Stressors were found to be significant predictors of Family $\rightarrow$ Work Conflict, as well as Work $\rightarrow$ Family Conflict. This finding implies that predictors of conflict in one domain may also be predictors of conflict in other domains, especially true for work $\rightarrow$ family related predictors. Thus, theoretical models in work-family literature attempting to portray a holistic understanding of the work-family interface may need to include indirect predictors of conflict as well.

Another predictor variable studied here was Gender. Based on results in the literature (Frone et al., 1992a\&b; Greenhaus et al., 1989; and Hall \& Richter, 1988) and the results of Hypothesis 3 in the present study, it appears that there is no gender difference in work -> family and family $\rightarrow$ work conflict spillover. Pleck's hypothesis (1977) based upon 
this gender difference appears to be no longer valid.

The final set of predictor variables assessed in the present study dealt with individual difference factors and included the Managerial Potential scale and the work Orientation scale. The use of these variables resulted in a modest increase in the explained variance of work $\rightarrow$ family and family $\rightarrow$ work conflict, and Work Orientation was determined to be the only significant predictor of Work $\rightarrow$ Family Conflict. These findings indicate that there are potential benefits in using individual difference factors. As previously mentioned the addition of these variables increased the explained variance, which in turn, could result in even a better understanding of the predictors of inter-role conflict.

\section{PRACTICAL IMPLICATIONS}

Aside from adding to our understanding of the work-family interface, the present study has laid the groundwork for a whole new arena of investigation within the domain of workfamily research. Discovering personality types and values systems that are significant predictors of work $\rightarrow$ family and/or family $\rightarrow$ work conflict would carry with it practical implications, as well as the theoretical implications mentioned above. In practical terms, individuals may be able 
to predict, based upon their personality profiles, whether or not they show a susceptibility to inter-role conflict. This information, in turn, could be used to help prevent future role conflict. Organizations could benefit as well by identifying those individuals that may be more prone to interrole conflict. This information, in turn, could assist the organization in determining which individuals show the greatest need for assistance and a preventative plan could be implemented.

Another practical implication that can be drawn from the present study involves the finding that there was a significant positive relationship between job stress and family $\rightarrow$ work conflict spillover. This finding suggests that lowering the levels of job stress for employees would not only benefit the individuals involved, but it may also benefit the organization by lowering the amount of family $\rightarrow$ work conflict spillover.

FUTURE RESEARCH NEEDS

The present study has several methodological limitations. The sample represented in the present study was from one department of one organization, which happened to be a civil service agency. Although the demographics appeared to be representative, the differences between public and private 
industry tends to limit the generalizability of these results to private industry. Causal relationships can not be determined from the data presented in this study because this study utilized cross-sectional, correlational data. The data in the present study were based on self-reports, which may reflect common source biases. However, this effect should be constant across all measured relationships.

Future research on the work-family interface should focus on several areas:

1) Continual assessment and improvement should be made in the construct scales used in work-family research. Current scales reliability and validity could be improved. For example, the directional scale for workfamily conflict (Frone et al., 1992b) consists of four items. Two items assess work $\rightarrow$ family conflict and two items assess family $\rightarrow$ work conflict. The addition of more items to this scale may result in better reliability coefficients and better reliability.

2) Recent studies all seem to indicate that a Gender difference no longer exists for inter-role conflict spillover, thus attention should begin to be turned elsewhere in discovering other predictors of how individuals will deal with their conflicting roles between work and family. Perhaps looking at individual differences, such as personality profiles and value 
systems, will result in new predictors (i.e., such as Managerial Potential \& Work Orientation).

3) Theoretically one would suspect that an individual's involvement in his or her job would be a significant indicator of work $\rightarrow$ family conflict or perhaps even family $\rightarrow$ work conflict, but this wasn't found to be the case in Frone et al. (1992b) or in the present study. Thus, future research should both re-evaluate the Job Involvement scale developed by Kanungo (1982) and reassess the theoretical relationship represented above. 
REFERENCES

Duxbury, L.E., \& Higgins, C.A. (1991). Gender differences in work-family conflict. Journal of Applied Psychology, $\underline{76}(1), 60-74$.

Evans, P. \& Bartolome, F. (1984). The changing pictures of the relationship between career and family. Journal of Occupational Behavior, $5,9-21$.

Frone, M.R., Russell, M., \& Cooper, M.L. (1992a). Prevalence of work-family conflict: Are work and family boundaries asymmetrically permeable? paper presented at the Annual conference of the Society for Industrial and Organizational Psychology, Montreal, Quebec, Canada.

Frone, M.R., Russell, M. , \& Cooper, M.L. (1992b). Antecedents and outcomes of work-family conflict: Testing a model of the work-family interface. Journal of Applied Psychology, $\underline{77}(1), 65-78$.

Goff, S.J., Mount, M.K., \& Jamison, R.L. (1990). Employer supported child care, work/family conflict, and absenteeism. Personnel Psychology, 43(4), 793-809.

Gough, H.G. (1984). A managerial potential scale for the California Psychological Inventory. Journal of Applied Psychology, 69(2), 233-240.

Gough, H.G. (1985). A work orientation scale for the California Psychological Inventory. Journal of Applied Psychology, 70 (3), 505-513.

Gough, H.G. (1987). California Psychological Inventory: Administrator's Guide. Palo Alto, CA.: Consulting Psychologists Press.

Greenhaus, J.H. \& Beutell, N.J. (1985). Sources of conflict between work and family roles. Academy of Management Review, 10 (1), 76-88.

Greenhaus, J.H., Parasuraman, S., Granrose, C.S., Rabinowitz, S., \& Beutell,N.J. (1989). Sources of work-family conflict among two-career couples. Journal of Vocational Behavior, 34, $133-153$. 
Hall, D.T. \& Richter, J. (1988). Balancing work life and home life: what can organizations do to help? The Academy of Management Executive, 11(3), 213-223.

Kahn, R.L., Wolfe, D.M., Quinn, R., Snoek, J.D., \& Rosenthal, R.A. (1964). Organizational Stress: Studies in Role Conflict and Ambiguity. New York : Wiley.

Kanungo, R.N. (1982). Measurement of job and work involvement. Journal of Applied Psychology, 67(3), 341349 .

Kopelman, R.E., Greenhaus, J.H., \& Connolly, T.F. (1983). A model of work, family, and interrole conflict: A construct validation study. Organizational Behavior and Human Performance, $\underline{32}, 198-215$.

Lambert, S.J. (1990). Processes linking work and family: A critical review and research agenda. Human Relations, $\underline{43}(3), 239-257$.

Lobel, S.A. (1991). Allocation of investment in work and family roles: Alternative theories and implications for research. Academy of Management Review, 16 (3), 507-521.

Offermann, L.R. \& Gowing, M.K. (1990). Organizations of the future: Changes and challenges. American Psychologist, $\underline{45}(2), 240-251$.

Pleck, J.H. (1977). The work-family role system. Social Problems, 24, 417-426.

Powell, G.N., Posner, B.Z., \& Schmidt, W.H. (1984). Sex effects on managerial value systems. Human Relations, 37(11), 909-921.

Rousseau, D.M. (1978). Relationship of work to nonwork. Journal of Applied Psychology, 63 (4), 513-517.

Shamir, B. (1983). Some antecedents of work-nonwork conflict. Journal of Vocational Behavior, 23, 98-111.

Sekaran, U. (1983). Factors influencing the quality of life in dual-career families. Journal of occupational Psychology, 56, 161-174. 
Yogev, S. \& Brett, J. (1985). Patterns of work and family involvement among single- and dual-earner couples. Journal of Applied Psychology, 70 (4), 754-768.

Zedeck, S. \& Mosier, K.I. (1990). Work in the family and employing organization. American Psychologist, 45(2), 240251. 
APPENDIX A

FRONE, RUSSELL, AND COOPER'S (1992b) CONCEPTUAL MODEL OF THE WORK-FAMILY INTERFACE 
Frone, Russell, \& Cooper's (1992a) Conceptual Model of The Work-Family Interface

Job Stressors

Job Distress

\author{
Work -> Family \\ Conflict
}

Job Involvement

Depression

Family Involvement

$$
\begin{gathered}
\text { Family }->\text { Work } \\
\text { Conflict }
\end{gathered}
$$

Family Stressors

Family Distress

+ = Positive Relationship _ - = Negative Relationship 
APPENDIX B

MODEL ILLUSTRATING TEST OF EACH PREDICTOR

FOR WORK $\rightarrow>$ FAMILY CONFLICT 
MODEL ILLUSTRATING PROPOSED TEST OF EACH PREDICTOR FOR WORK $\rightarrow$ FAMILY CONFLICT

Job Stressors

Job Involvement

Gender

Managerial Potential Work $\rightarrow$ Family Conflict

Work Orientation

Family Stressors

Family Involvement 
APPENDIX C

QUESTIONNAIRE 


\section{Empiovee Surve:}

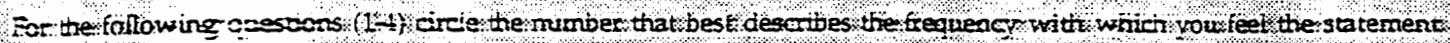
apoies to yous :

i) Zow orten does $: 0-\pi$ or career intriere with your responsibuitues a: iome. such as $: z=-\pi x$ soking, sieaning, tepaurs, shopping, payng the juils. or civid 3 ?

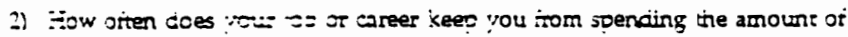

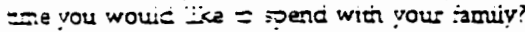

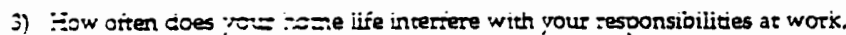
suen as gereng = wex $\mathrm{m}$ the. acsonpiising daiy asks. or working vverane?

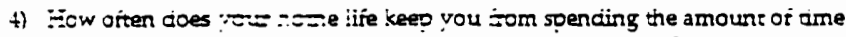
you would like $\approx$ see: $=$ an joi or sireer-reiared activines?

\begin{tabular}{|c|c|c|c|c|}
\hline $\begin{array}{l}\text { ALMOST } \\
\text { NEVER }\end{array}$ & OCESTONAL: & $\begin{array}{l}\text { ABOCT :HLE } \\
\text { OII TME }\end{array}$ & FREQUENTL & $\begin{array}{l}\text { ALNOST } \\
\text { AWAYS }\end{array}$ \\
\hline$\vdots$ & 2 & ; & 4 & j \\
\hline$i$ & $\vdots$ & 3 & 4 & j \\
\hline : & 2 & 3 & 4 & 5 \\
\hline$\vdots$ & $\because$ & $j$ & $t$ & j \\
\hline
\end{tabular}

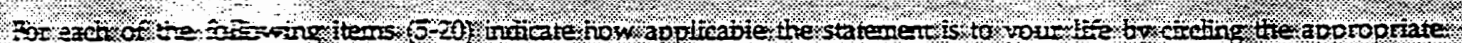

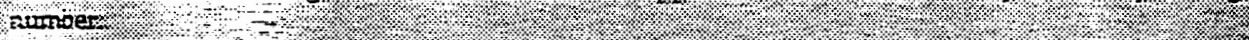

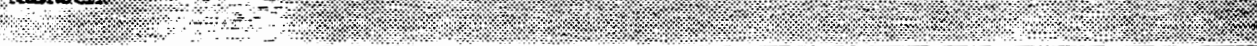

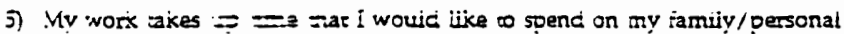
ije.

5) Vy worx sciecie

7) Ky samiiy disiikes :ow siten I an oreocsipied with my work winile I am at jome.

8) Afrer work. I =ne scee too tred o do some of the things I would like to so.

9) On the job I iave $\approx=$ : riterests.

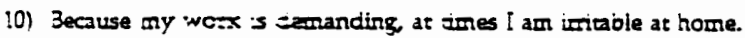

i1) The demancs $\div$ :

ia) Vy joi makes : : would ike so je

\begin{tabular}{|c|c|c|c|c|}
\hline $\begin{array}{l}\text { minONCLY } \\
\text { JSACREe }\end{array}$ & 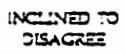 & $\begin{array}{l}\text { VETHER AGNE } \\
\text { NOR OTSACRES }\end{array}$ & $\begin{array}{l}\text { MONNED } \\
\text { TOANEI }\end{array}$ & $\begin{array}{l}\text { Strona: } \\
\text { tGane }\end{array}$ \\
\hline$:$ & 2 & 3 & 4 & j \\
\hline 1 & 2 & $j$ & 1 & 5 \\
\hline 1 & 2 & 3 & 4 & j \\
\hline & & - & & \\
\hline 1 & 2 & 3 & 4 & 5 \\
\hline 1 & 2 & 3 & 4 & 5 \\
\hline 1 & 2 & 3 & 4 & 5 \\
\hline ? & 2 & 3 & 4 & 5 \\
\hline : & 2 & 3 & 4 & 5 \\
\hline ! & $=$ & 3 & \pm & 5 \\
\hline 1 & 2 & 3 & 4 & 5 \\
\hline 1 & $=$ & 3 & 4 & 5 \\
\hline$i$ & 2 & 3 & 4 & 5 \\
\hline
\end{tabular}

6) When I go to rox : in too ared to co some of the things i woujd like to so.

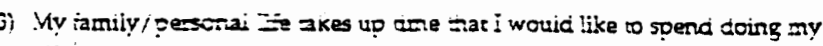
Nork.

14) My amily/ geserai Ze oiven conriics with my work scheciule.

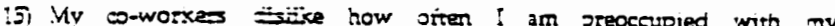
ianily/pesconai ize wrie I am ar work. 
17. th come. I have io =any resconsioilitues that it bikes sway fom ny

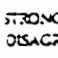

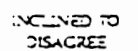

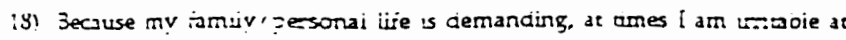
vork.

(9) The Eemands ot $=. \%$ z-xiy/personai life gakes it nore diricult to be ceiaxec rnie at ror.

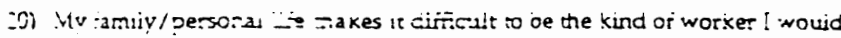
iixe to se.

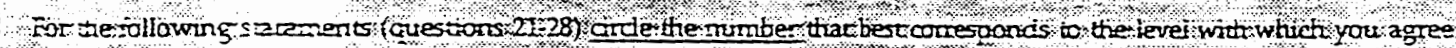
or disagree tatticie saments.

$1.1 .1 .1 .0 \%$

1.

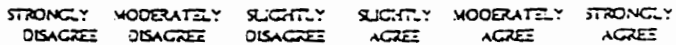

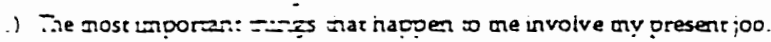

$\therefore$ in very auch persenily invoivec vith my job.

i) i ive. eat and oreatie $=:$;:00.

1) Most of any intereso izerer around ny jod.

Si I have very strong =o wo any gresent jod which wouid je very cirest to areak

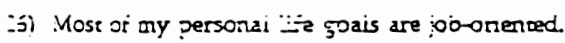

7) I consicier ny joo to se ver! centosi to any existence

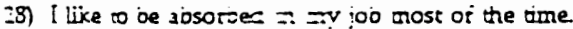

$\begin{array}{lllllll}1 & 2 & j & 4 & j & j \\ 1 & 2 & j & 1 & j & 6 \\ 1 & 2 & 3 & 4 & j & 6 \\ i & 2 & j & 4 & j & 6 \\ 1 & 2 & j & 4 & j & 6 \\ 1 & 2 & 3 & 4 & j & 6 \\ 1 & 2 & 3 & 4 & j & 6 \\ 1 & 2 & 3 & i & j & 6\end{array}$

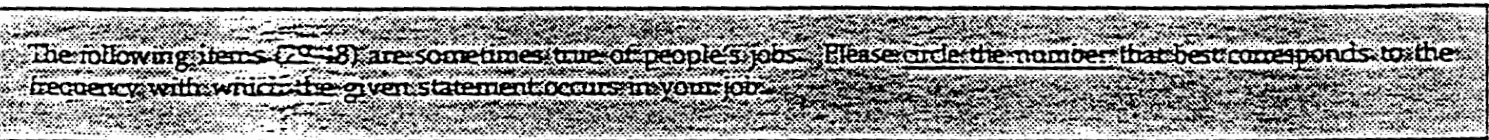

(9) Do vou have too al: work do do?

i0) tre you unsure asch: wrat peopie expec or you?

ji) So vou reel that :ou $3-9$ Jable to irtluence vour supervisor's decions even when they itor: rou?

i2) Do you reel that yot :ave 3 lor of resoonsibuily for the worx of others?

j) 20 you wotx ver: $-2=-$ sher pirsicaily or mentaily?

j4) Can you use your zNT. Jearve o do things?

35) ire you uncer presirte D keep up with the new ways of coing tungs?

\begin{tabular}{|c|c|c|c|}
\hline 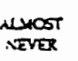 & SOMETDES & ORTEN & $\begin{array}{l}\text { ALWOST } \\
\text { ALWAYS }\end{array}$ \\
\hline 1 & 2 & 3 & 4 \\
\hline$:$ & : & j & 4 \\
\hline$i$ & 2 & 3 & 4 \\
\hline 1 & $I$ & 3 & 4 \\
\hline i & 2 & 3 & 4 \\
\hline 1 & $:$ & j & 4 \\
\hline 1 & 2 & 3 & 4 \\
\hline
\end{tabular}




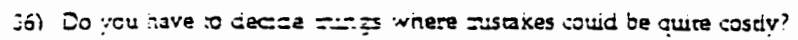

\begin{tabular}{|c|c|c|c|}
\hline $\begin{array}{l}\text { NACES } \\
\text { VETEE }\end{array}$ & SOME:MEE & $O F E N$ & $\begin{array}{l}\text { ALAOST } \\
\text { ALivars }\end{array}$ \\
\hline : & : & j & $\div$ \\
\hline$\vdots$ & $\Xi$ & 3 & \pm \\
\hline : & $=$ & 3 & 4 \\
\hline : & : & ; & $t$ \\
\hline : & $=$ & 3 & + \\
\hline : & : & 3 & 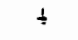 \\
\hline : & : & ; & 4 \\
\hline : & : & $\vdots$ & $\div$ \\
\hline : & $=$ & 3 & 4 \\
\hline : & $:$ & ; & + \\
\hline : & $:$ & ; & $t$ \\
\hline$\vdots$ & $\Xi$ & 3 & $t$ \\
\hline$:$ & $=$ & 3 & 4 \\
\hline
\end{tabular}

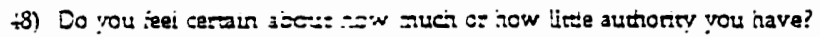

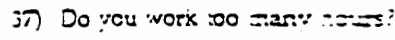

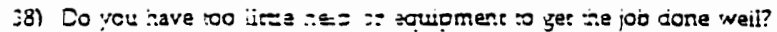

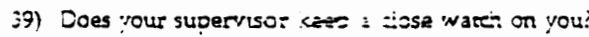

(5) Do you have imporz: :

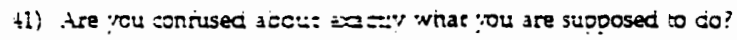

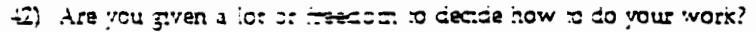

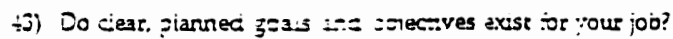

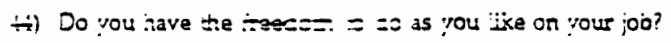

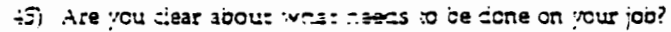

6) Are vou encouragec $==1$ ca your own Eec:sions?

th Co rou know exacsin vis: is expecsed st you?

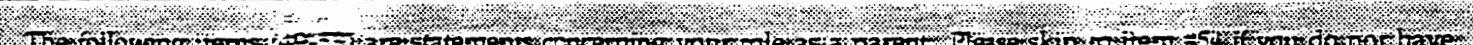

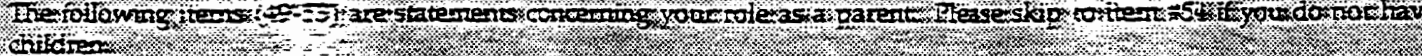

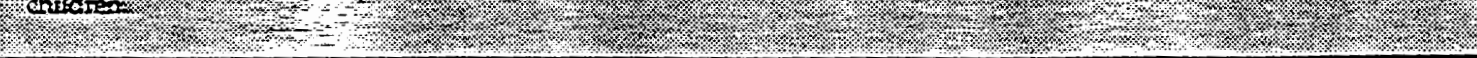

\begin{tabular}{|c|c|c|c|c|c|c|c|}
\hline & & $\begin{array}{l}\text { MRONCIYY } \\
\text { OISACREE }\end{array}$ & 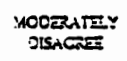 & 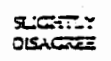 & 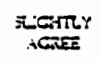 & $\begin{array}{l}\text { MODERUTE: } \\
\text { NOREL }\end{array}$ & $\begin{array}{l}\text { STRONGE: } \\
\text { AGREE }\end{array}$ \\
\hline 49) & 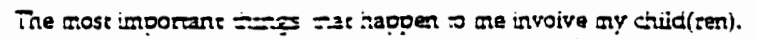 & $i$ & 2 & ; & \pm & 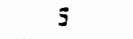 & 6 \\
\hline (3)) & I am very nues persceas:- zyoived with ny exid(ren). & $:$ & $\vdots$ & ; & 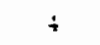 & s & 6 \\
\hline si) & Most or ny interess are =erered arounc sy civid(ren). & 1 & 2 & 3 & + & 5 & á \\
\hline 52) & To ne. Jenng a fatre: $=0=2$ ! is a very larga part of who $i \mathrm{am}$. & ? & 2 & $\Sigma$ & + & 3 & 6 \\
\hline 53) & My ciid(ren) (is/are: a re? =portant part or my life. & : & $?$ & 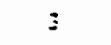 & $t$ & j & 6 \\
\hline \multicolumn{8}{|c|}{ 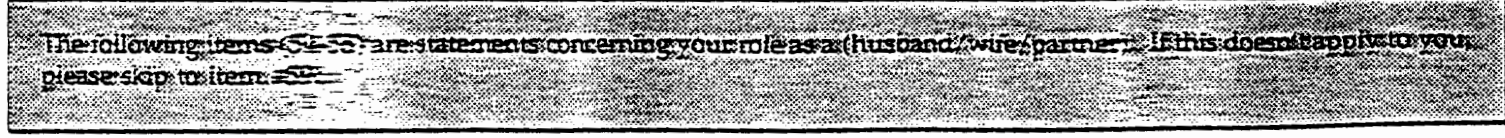 } \\
\hline & & $\begin{array}{l}\text { THONCLY } \\
\text { OLSAGREE }\end{array}$ & $\begin{array}{l}\text { Mocrute: } \\
\text { OLsianas }\end{array}$ & 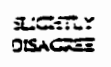 & 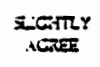 & $\begin{array}{l}\text { WODERATE: } \\
\text { AGEFE }\end{array}$ & 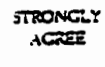 \\
\hline इ4) & 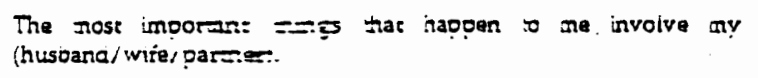 & 1 & 2 & ; & 4 & 5 & $\hat{s}$ \\
\hline 5) & 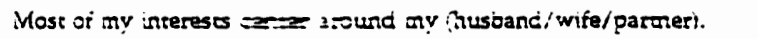 & ! & $:$ & $\xi$ & + & 5 & 6 \\
\hline
\end{tabular}




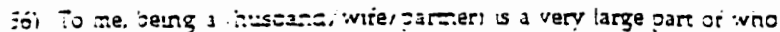

M

i am.

in i am vary =:0: perscraily involved with ny (husoanci vie, par=a

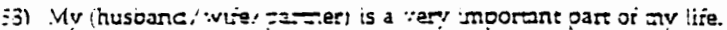

$\begin{array}{llllll}\vdots & 2 & \vdots & 4 & \vdots & 0 \\ \vdots & 2 & 3 & 4 & \vdots & 0 \\ 1 & 2 & 3 & 1 & 5\end{array}$

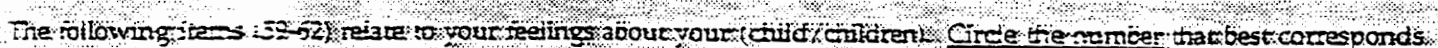

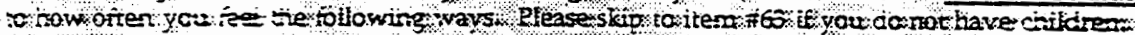

0
1

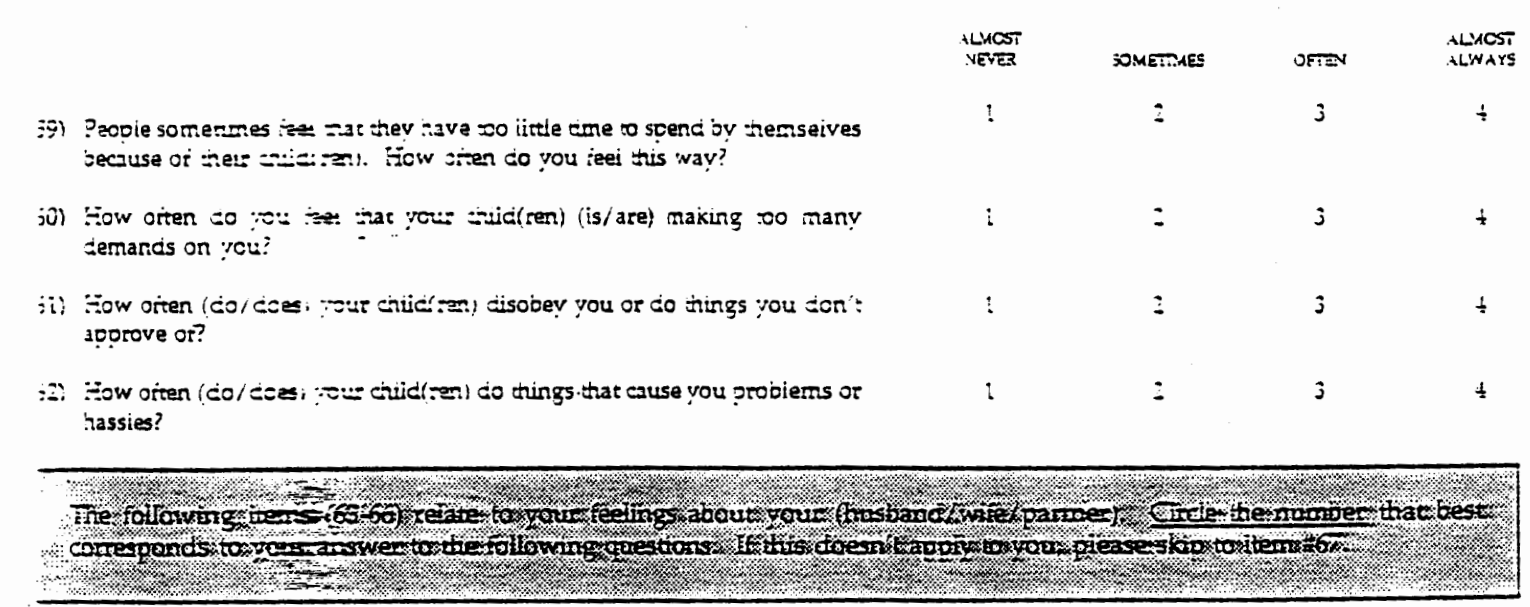

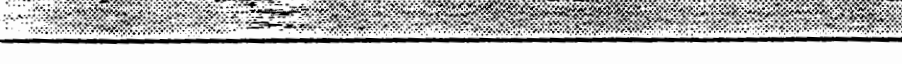

3) Eow muci: can yos sesend on (hin / her) to be there when you reaily need

vOT ATALL

ONCALTE

SOMENHAT

icositose (hin/her)?

ji) Fow muci concers jes (he/sne) sinow for your feaings and proolems?

jọ Fow nuci :exsion is there becween you and your (husband/wire/pargert?

$\begin{array}{llll}1 & = & 3 & 4 \\ 1 & = & 3 & 4 \\ 1 & = & 3 & 4\end{array}$

o) "Nouid you say ros zec rour (husieand/wire/parnes) have an unoleasant

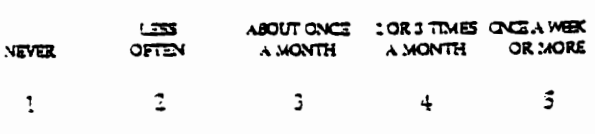

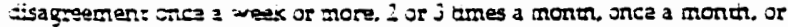
'ess orten? 


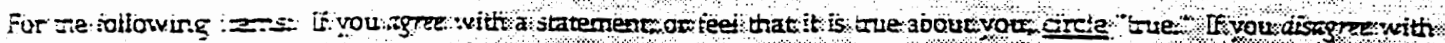

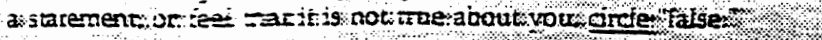

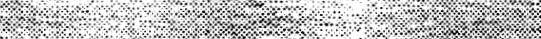

in ! have hac rery zectiz: ind strange excerzences.

TRLE

FALSE

j8) in rost ways, a y=c: zerson is berter sit than a ach one.

RUE

PALEE

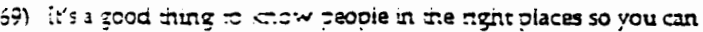

TRLE

FALSE get intic texers. :

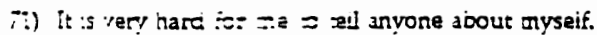

TRLE

FALSE

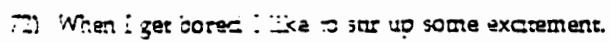

TRUE

BALEE

i3) I ivcuic so aimes: $A-:=-2 \pi g$ on a dare.

TRLE

FALSE

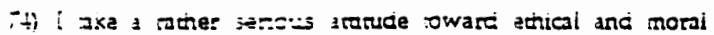
isรites.

TRLE

FALEE

7 I have no dreac s: $:=23$ tho a soon jy myseif where other jecpie have aireze: $\$=$ sered and are siking.

76) I je? grenty dis

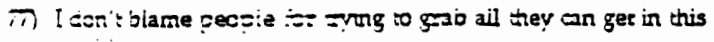
woric.

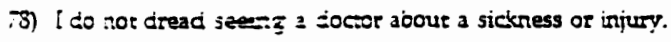

79) If ael as good icen as: sver have.

FALE

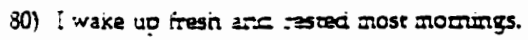

TRUE

EALSE

81) It is hard bor the :ust = sit sall and teiax.

TRUE

EALSE

32) Most geople will use scoswhat uriair greans to gain protit or an acvantage istie zan w iose it

TRUE

FALSE

83) I have surange arce peciast fougints.

TRLE

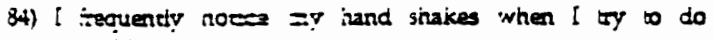
somezing.

TRLE

FALSE

TRUE

FALSE

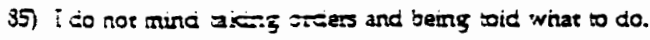

TRUE

EALSE

36) Teachers orten excec= $=0$ much work Sirn stucients.

TRUE

F.ALEE

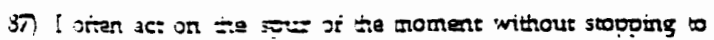
Junx.

RUE

FALSE

38) My ivay oi doing $=0$ is apt to be misunderstood by others.

TRUE

FALSE

39) I am serminily iacs:

TRUE

FALSE

90) Vy parents have gosesily let me make ny own decsions.

TRUE

FALSE

91) I have had more =.2n =y share of things to worry abous

TRUE

FALSE 
$\therefore$ I am quite ormen nc: a : in gossip and alk of the group I beiong to.

33) Criy a cooi ivouic swe tote to incease his own axes.

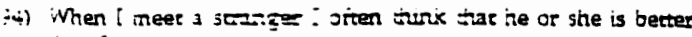
than i am.

TRUE

FALSE

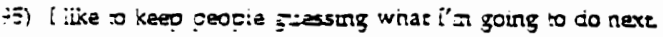

TRUE

EAL

$\therefore$ if joen the chance: :verce rake a zood leader of people.

RUE

FALSE

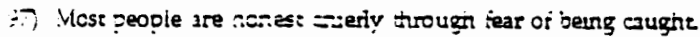

28) Ecmenues ( $:$ eei $=.1:: z=$ aboue to go to pieces.

TRUE

EALSE

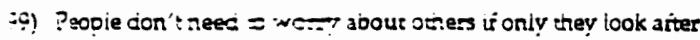
nemseives.

TRUE

FALSE

(10) Fon ine o cre : قre o ger compiereiy dway from worx and dnvthing fat :-ses of :

TRE

EALE

TRLE

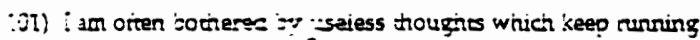
stougin ny nure

FAL

:021 Most of the ine : ingoy.

TRLE

$F+\sqrt{S C}$

(9) l someanes iee $\div 2:: 30$ a burcien 0 others.

TRLE

FALSE

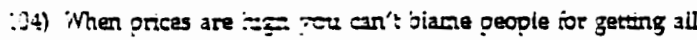
tey an ivinie =e $=5$ is gocc.

FALSE

:.5)! oren feei as tors: : have cone sometining wrong or rickeci.

EALSE

:06) I usuaily te tas is is rorthwivie

BALSE

în Lubreakers are simose aiways ougint and punished.

TRUE

FAISE

(08) ! think most peoçie mocic lie to get anead.

EAISE

:09) I am a betrer alkes: =ise a iscener.

TRUE

EALSE

$:: 0)$ in prent sure i cow sow we can sentio he intematonal probiems we race sery.

FALSE

:II) I have very tew cares with members of Iny facriy.

EALSE

i:? ! lika to read abot $=000$.

EAISE

::2) it is hard tor ne $=$ ac aruma when I am with new people.

EALSE

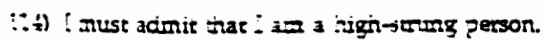

EALSE

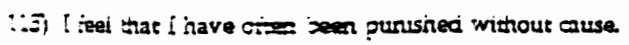

RUE

FACSE

:6) i dor': seen to are mar iappens to one.

FALSE

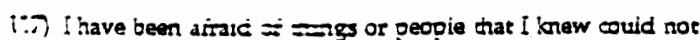
hure the.

TRUE

EALSE

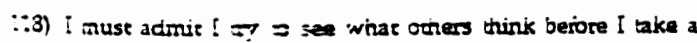
sand.

TRUE

FALSE 
(12) : have never sone 2 n: :eavy arsixing.

\begin{tabular}{|c|c|}
\hline RLE & $E A L E E$ \\
\hline TRUE & FALSE \\
\hline IRLE & FALSE \\
\hline RUE & $\because A L S E$ \\
\hline RLE & BALE \\
\hline TRLE & EALSE \\
\hline RLE & FALSE \\
\hline RLE & FALSE \\
\hline TRLE & FALEE \\
\hline TRLE & $E A L S E$ \\
\hline RUE & FALEE \\
\hline RLE & BALSE \\
\hline RUE & FALSE \\
\hline TRLE & FALSE \\
\hline TRLE & FALSE \\
\hline IRLE & EALSE \\
\hline TRUE & BALSE \\
\hline IRU & FALSE \\
\hline
\end{tabular}

120) Some of my iansiy asve nabis that cother and annoy me very muen.

(21) Vo one seems of :ceersand me.

PALE

120) : Sinix I an usuaìy a iencer in my group.

ALE

124) $i$ enoy pianning $=5$ s. and deccing what each person snouid do.

125! Success is a garter s: in power.

ALSE

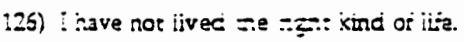

127) : Cavdream ve?! ':

PALE

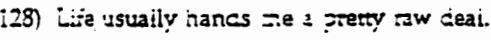

129) I have a good acsess

ALSE

(30) ?eople oiten zik aocu: =ee dehind gy jack.

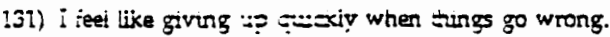

FALE

(32) . Wy simn seems to se =:":sually sensicie to touch.

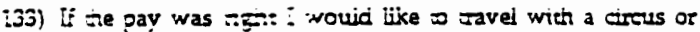
samivai.

134) Pecoie seen naruziily = הلn to the when decisions have to be arae.

ALSE

135) My sleep is tituri anc sistried.

FALSE

136) It seens that pecpie -used to have gore run than they do now. 
